\title{
MENINO, GURI OU PIÁ? UM ESTUDO DIATÓPICO NAS REGIÕES CENTRO- OESTE, SUDESTE E SUL A PARTIR DOS DADOS DO PROJETO ATLAS LINGUÍSTICO DO BRASIL
}

\author{
Valter Pereira ROMANO* \\ Rodrigo Duarte SEABRA **
}

- RESUMO: Este trabalho utiliza como corpus de análise os dados coletados pela equipe do Projeto Atlas Linguístico do Brasil em três regiões: Centro-Oeste, Sudeste e Sul. Os dados referem-se às cidades do interior e às capitais de cada estado, coletados junto a informantes selecionados segundo o perfil estabelecido. Nesta oportunidade, objetiva-se discutir a distribuição diatópica das variantes lexicais para a questão 132 - "Criança pequenininha, a gente diz que é bebê. E quando ela tem de 5 a 10 anos, do sexo masculino?" - do Questionário Semântico-Lexical (COMITÊ NACIONAL DO PROJETO ALIB, 2001). A metodologia utilizada envolveu análises descritivas e inferenciais pertinentes ao estudo. Para tanto, oito hipóteses foram testadas no sentido de averiguar o comportamento e a distribuição diatópica das cinco variantes mais produtivas no conjunto de respostas. Os principais resultados observados indicam que as variantes apresentam comportamento distinto nas três regiões: (i) a variante "menino" apresenta distribuição homogênea nos dez estados; (ii) as formas lexicais "guri" e "piá" possuem distribuição heterogênea na região Sul; (iii) as variantes de etimologia indígena ("guri" e "piá") são mais representativas nas regiões Sul e Centro-Oeste; (iv) há uma maior representatividade da variante "moleque" (étimo africano) na região Sudeste, principalmente em São Paulo e Minas Gerais.

- PALAVRAS-CHAVE: Projeto ALiB. Dialetologia. Variantes lexicais.

\section{Introdução}

O léxico de uma língua é o conjunto de palavras criadas e assimiladas pelo homem no decorrer da história e resulta do processo de nomeação e de interação daquele com o meio em que vive. É gerado ao longo do tempo e, por meio de seu estudo, é possível detectar influências socioculturais e históricas adquiridas em seu processo de formação. Segundo Isquerdo (2007), o léxico representa ainda

\footnotetext{
* UEL - Universidade Estadual de Londrina. Centro de Letras e Ciências Humanas. Londrina - PR - Brasil. 86051 980 - valter.romano@hotmail.com

** UNIFEI - Universidade Federal de Itajubá. Instituto de Matemática e Computação. Itajubá - MG - Brasil. 37500-903 - rdsea@hotmail.com
} 
um aspecto diferenciador no que se refere à variação linguística, sobretudo, a geográfica, pois além de evidenciar diferenças de uma região para outra, demonstra também a consequente mobilidade dessas diferenças de um espaço para outro. Dessa forma, verificar as especificidades lexicais de cada área geográfica é uma tarefa desafiadora, dada a dinamicidade da língua e a disseminação de variantes.

Os dados coletados para a elaboração do Atlas Linguístico do Brasil ${ }^{1}$ têm contribuído para a descrição do léxico das diversas regiões do país. Dentre os trabalhos mais recentes, citam-se como exemplos os de Isquerdo (2009), Romano e Aguilera (2009), Aguilera (2010), Silva e Aguilera (2010), Paim (2011), Yida (2011), Silva-Costa e Isquerdo (2012) e Marins (2012), dentre outros. Esses trabalhos apontam para as diferenças regionais do léxico do português brasileiro, ora confirmando a proposta de divisão dialetal de Nascentes (1953), sob a perspectiva lexical, ora evidenciando particularidades que caracterizam cada uma das regiões, sobretudo, por influências sócio-históricas do processo de ocupação e povoamento.

Interessa-se, neste estudo, verificar a variação lexical dos designativos para "a criança que tem entre cinco e 10 anos do sexo masculino" relativa à questão 132 do Questionário Semântico Lexical (QSL) do ALiB junto a informantes naturais de três regiões brasileiras: Sul, Sudeste e Centro-Oeste. Busca-se, portanto, na história social de cada uma dessas regiões, os indícios da motivação para a predominância de uma variante em detrimento de outras.

\section{Breve quadro histórico: os processos de ocupação}

O povoamento e desenvolvimento das regiões Sudeste, Centro-Oeste e Sul do Brasil deve-se a três importantes movimentos de ocupação humana: às Bandeiras, ao Tropeirismo e à Marcha para o Oeste. Esses movimentos deixaram marcas em cada um dos estados interferindo na cultura e nos hábitos dos grupos humanos que ali se formaram, dentre as quais interessam-se as deixadas no léxico, que evidenciam rastros da sócio-história.

Sabe-se que a ocupação do interior do Brasil não ocorreu imediatamente à chegada dos portugueses à nova terra, pois, inicialmente, o processo de ocupação deu-se "[...] em face das condições apresentadas pelo meio físico." (DIÉGUES

\footnotetext{
O Projeto Atlas Linguístico do Brasil, doravante ALiB, é um projeto de pesquisa nacional e interinstitucional, com sede na Universidade Federal da Bahia, sob a presidência da Dra. Suzana Alice Marcelino Cardoso e dirigido por um Comitê Nacional formado por pesquisadores de universidades de oito estados. O Projeto ALiB visa a descrever a variante brasileira da língua portuguesa nos níveis fonético-fonológico, semântico-lexical e morfossintático, por meio da aplicação de questionários a informantes de todo território nacional, para, assim, formar um banco de dados que posteriormente será utilizado para a elaboração de um Atlas Linguístico de âmbito nacional. Mais informações podem ser obtidas em: <http://twiki.ufba.br/twiki/bin/view/Alib/ WebHome>.
} 
JÚNIOR, 1960, p.38). Assim, de início, os colonizadores ocuparam o litoral do país, desenvolvendo a vida colonial em dois núcleos principais, um localizado ao nordeste (Pernambuco/Bahia) e um ao sul (São Paulo).

De acordo com Ribeiro (1995, p.364), "[...] enquanto os núcleos açucareiros da costa nordestina cresciam e enriqueciam, a população paulista revolvia-se numa economia de pobreza.", desenvolvendo-se ali uma sociedade esparsa.

Essa pobreza, que está na base tanto das motivações quanto dos hábitos e do caráter do paulista antigo, é que fazia deles um bando de aventureiros sempre disponível para qualquer tarefa desesperada, sempre mais predispostos ao saqueio que à produção. (RIBEIRO, 1995, p.365).

No afã de aprisionar índios arredios e principalmente encontrar metais preciosos, a população paulista começou a se deslocar para o interior. Nas palavras de Diégues Júnior (1960, p.235), "Saem de São Paulo as bandeiras que vão devassar os sertões; penetração que se inicia no século XVI, se desenvolve no XVII e alcança a sua fase de esplendor no século XVIII." Assim, foi a partir da capitania de São Vicente que se irradiou a ocupação territorial para o sul e para o centro; igualmente para o oeste.

Em direção norte de São Paulo o bandeirismo realizou a empresa de desbravamento do território atual das Minas Gerais. E em direção oeste foram alcançados por um caminho, Cuiabá, e por outro - êste, através do território mineiro - Goiás. (DIÉGUES JÚNIOR, 1960, p.272).

Em direção ao sul do país, não foi diferente a motivação dos bandeirantes paulistas; porém, se não encontravam ouro, encontravam os bandeirantes outro motivo para continuarem a caminhada: apareceram campos e campinas adequados para a criação de animais de carga.

Sabe-se que, já nos começos do século XVII, bandeirantes paulistas assolavam o território que é hoje o Paraná, seguindo-se para a ilha de Santa Catarina, atualmente Florianópolis; e, nessa marcha para o sul, chegaram à Laguna (DIÉGUES JÚNIOR, 1960). Porém, com o passar do tempo, muitos homens bandeirantes que inicialmente se dedicavam ao apresamento dos indígenas e à exploração de metais preciosos se fixaram em terras no sul e, paulatinamente, foram se integrando ao pequeno comércio praticado ali no lombo de mulas.

Ao longo do século XVIII, a economia colonial crescia e consequentemente acentuava-se a necessidade de abastecimento de gêneros alimentícios das cidades que floresciam, principalmente, em Minas Gerais. Com o advento das minas de ouro, houve um aumento da demanda de carne (charque) e também de couro para os alforjes do transporte do ouro à corte portuguesa. A solução 
foi recorrer ao transporte desses materiais às mulas, animais resistentes à carga e às longas distâncias em caminhos muitas vezes impraticáveis, vindos do sul para a região mineradora. Dessa forma, surgiu uma nova economia baseada no transporte e comércio desses animais, o Tropeirismo.

Os tropeiros saíam do Rio Grande do Sul, cruzavam o Paraná, com destino a Sorocaba, no Estado de São Paulo, onde ocorriam durante todo o ano grandes feiras para a comercialização dos animais e gêneros para os garimpeiros e exploradores. Uma das rotas mais importantes é o denominado Caminho de Viamão, que saía de Campos de Viamão (RS), passando por Vacaria (RS), Lages e Curitibanos (SC), Rio Negro, Lapa, Palmeira, Ponta Grossa, Castro, Piraí do Sul e Jaguariaíva (PR), Itapetininga e Sorocaba (SP). Além desse movimento efetuar o escoamento da produção econômica, deve-se a ele a difusão de hábitos e costumes, haja vista que os tropeiros levavam consigo a sua cultura por onde passavam, sendo responsáveis pelo florescimento de cidades que se iniciaram com os ranchos das tropas (STECA; FLORES, 2002). Porém, com o passar do tempo, o desenvolvimento da sociedade cafeeira e o investimento dos grandes barões na rede ferroviária, atrelado às melhorias no transporte fluvial, levaram o movimento das tropas ao declínio, sendo gradativamente absorvido por outras formas de transporte.

Se, na região Sul, houve a intensiva influência dos tropeiros no processo de ocupação e povoamento; no Centro-Oeste, foi marcante a influência do movimento denominado Marcha para o Oeste, plano governamental que teve seu início durante o Estado Novo no mandato do presidente Getúlio Vargas.

No cenário da Segunda Guerra Mundial, difundia-se a ideia do "Espaço Vital", ou seja, o ideal de que os países mais desenvolvidos deveriam ocupar áreas pouco exploradas pertencentes aos países menos desenvolvidos, o que colocava a região Centro-Oeste do Brasil como um alvo potencial para ocupação (MANDEL, 1989). Ameaçado por esse prognóstico, o governo brasileiro decidiu promover a ocupação e o progresso do Centro-Oeste, subsidiando o acesso às terras com a finalidade de diminuir o desequilíbrio demográfico e incentivar a migração para as áreas que produziam a matéria-prima e os alimentos, o que contribuiria, consequentemente, à industrialização do Sudeste do país. Dessa forma, essa região até então pouco habitada passou a receber migrantes de todos estados brasileiros, o que promoveu um intenso progresso e um aumento demográfico significativo (DUARTE, 1989).

Assim, esses movimentos de ocupação e povoamento deixaram marcas na economia e, principalmente, na cultura dessas regiões, bem como rastros de um mosaico lexical que se compõe e evidencia traços da sócio-história de cada região. 


\section{Registro das principais variantes nas fontes lexicográficas}

O questionário do Projeto ALiB apresenta 15 questões referentes à subárea semântica "Ciclos da Vida", das quais, para este trabalho, foi selecionada a questão de n 132, que traz no caput a seguinte formulação: "Criança pequenininha, a gente diz que é bebê, e quando ela tem de 5 a 10 anos, do sexo masculino?" (COMITÊ NACIONAL DO PROJETO ALIB, 2001, p.31). Dentre as possíveis respostas, espera-se que os informantes apresentem itens lexicais como: "menino", "garoto", "moleque", "guri" e "piá", dependendo da localidade ou até mesmo do sexo, idade ou escolaridade dos informantes.

Cada um desses itens apresenta diferentes formações etimológicas e diferentes datações na língua portuguesa, o que revela traços da formação sóciohistórica do português. Assim, foram consultados sete dicionários para verificar as acepções, a datação e a etimologia de cada um dos vocábulos, a saber: dois dicionários antigos, Bluteau (1728) e Silva (1813); dois dicionários contemporâneos gerais do português, Houaiss e Villar (2001) e Ferreira (2004); dois etimológicos, Nascentes (1966) e Cunha (1986), e um dicionário histórico específico em palavras de origem tupi, Cunha (1999).

O vocábulo "menino" está registrado tanto em Bluteau (1728) quanto em Silva (1813) com a mesma acepção "Rapaz, que ainda não chegou aos sete anos de idade" (BLUTEAU, 1728, p.422) e "Diz-se da idade do homem até 7 annos" (SILVA, 1813, p.288). Nascentes (1966) afirma que o vocábulo tem origem controversa e, de acordo com Cunha (1986) e Houaiss e Villar (2001), data do século XIII, documentado nas fichas do Vocabulário Português Medieval. Sobre a etimologia do vocábulo, Houaiss e Villar (2001) afirmam que Corominas rejeita a hipótese de a palavra "menino", em português, ser um empréstimo do espanhol; para o dicionarista, trata-se de um de tantos termos acariciativos que as mães inventam para os seus filhos e, nessas condições, explica-se que o vocábulo seja aparentado com o francês antigo mignot (sXIII), modificado para mignon, "gracioso, gentil, bonito", no catalão (sXIII) apresenta-se como minyó "rapaz"; forma histórica. sXIII menino, sXIII menyo, sXIII mininno, 1345, meninho, sXIV menihos, sXV mynyno.

O vocábulo "garoto", nos dicionários consultados, apresenta dentre outras acepções algumas que se referem à criança, na maioria das vezes, com sentido pejorativo. Bluteau (1728) não registra esse vocábulo e somente em Silva (1813) se encontra o primeiro registro na língua. Segundo o lexicógrafo, o vocábulo refere-se ao "rapaz brejeiro, mal criado, petulante" (SILVA, 1813, p.80). Em Houaiss e Villar (2001), o verbete "garoto" apresenta quatro acepções, das quais duas concernem à criança do sexo masculino, sendo uma de caráter depreciativo: (i) "diz-se do rapaz ou menino que brinca ou anda vadiando pelas ruas"; e (ii) "rapaz imberbe, 
adolescente, menino". Em Ferreira (2004), dentre as sete acepções abonadas, destacam-se três, das quais duas também atribuem um caráter negativo à forma lexical: (i) "que brinca ou anda vadiando pelas ruas; travesso"; (ii) "rapaz sem educação, que anda a vadiar pelas ruas"; e (iii) "rapaz imberbe" (FERREIRA, 2004). Segundo Cunha (1986), a origem etimológica do vocábulo é obscura; porém, Nascentes (1966, p.351) afirma que "José Pedro Machado vê em -oto um sufixo diminutivo e relaciona o radical com o francês gars.", ou seja, garçon, vocábulo este usado na língua francesa, de acordo com o Dicionário Larousse (GALVEZ, 2005, p.159), para designar o "menino", assim como gamin.

O item lexical "moleque" demonstra a influência das línguas africanas no léxico do português. Bluteau (1728, p.541) não considera esse vocábulo como uma forma típica do português europeu, pois, no verbete "moleque", afirma que "Veyo-nos esta palavra do Brasil". Cunha (1986, p.528) registra que esse vocábulo veio do quimbundo mu'leke, para designar o "menino", "rapazote" com a datação de 1731 e, no século XIX, essa forma lexical já se encontrava dicionarizada, pois Silva (1813, p.310) registra que "moleque" é o "pretinho, negro pequeno". Ferreira (2004) apresenta dez acepções para o vocábulo, das quais destacam-se as quatro primeiras: "1.Negrinho. 2.Bras. Indivíduo sem palavra, ou sem gravidade. 3.Bras. Canalha, patife, velhaco. 4.Bras. Menino de pouca idade." (FERREIRA, 2004). Houaiss e Villar (2001), por sua vez, apresentam dezessete acepções para o verbete "moleque" das quais 13 são para emprego como substantivo masculino e quatro como adjetivo. Merecem destaque as seguintes acepções: "1. menino novo, de raça negra ou mista. 2. garoto de pouca idade. 3. menino criado à solta; menino de rua. 4. garoto travesso." (HOUAISS; VILLAR, 2001). Segundo este mesmo lexicógrafo, a forma lexical "moleque" é usada também em Moçambique para designar o empregado doméstico geralmente em fase escolar.

As outras duas formas lexicais ("piá" e "guri"), por sua vez, evidenciam a influência das línguas indígenas no português. Nenhuma das duas formas se encontra documentada em Bluteau (1728) e Silva (1813). De acordo com Cunha (1986), a forma lexical "guri" veio do tupi ü i"ri com a acepção que designa o "bagre novo" (tipo de peixe), por extensão de sentido, a criança. Ainda nesta entrada, o etimologista remete o usuário ao verbete "guiri - 'sm bagre' / curi 1587, guori datada aproximadamente 1631". Houaiss e Villar (2001), em contrapartida, registram a datação de 1890, documentada no Dicionário Etimológico da Língua Portuguesa de José Pedro Machado (1952). Para o lexicógrafo, dentre outras acepções, trata-se de um regionalismo brasileiro para designar o "menino", a "criança". Ferreira (2004), apesar de apresentar a mesma acepção para o vocábulo, traz outra etimologia. Segundo o dicionarista, o vocábulo "guri" também vem do tupi, porém com o sentido de pequeno, não fazendo, portanto, alusão ao peixe. 
No entanto, Nascentes (1966) esclarece que o vocábulo "guri" veio do tupi ki’ri "pequeno" e afirma que se trata do "bagre nôvo", por metáfora: "criança", portanto, em consonância ao que afirma Cunha (1986).

Quanto ao vocábulo "piá", os dois dicionários mais antigos da língua portuguesa, Bluteau (1728) e Silva (1813), e os dois dicionários de Cunha, um etimológico (1986) e um histórico sobre as palavras portuguesas de origem tupi (1999), não registram o verbete. Encontra-se em Nascentes (1966, p.578) que o item é de origem tupi, pi"á, e designa o "coração, estômago, entranhas, vetrecha, miúdos" e, por extensão, o "produto das entranhas". De acordo com Houaiss e Villar (2001), o verbete refere-se ao menino indígena e, analogamente, é empregado para se referir ao menino mestiço de indígena com branco ou mesmo qualquer criança do sexo masculino. Ainda segundo o lexicógrafo, trata-se de um regionalismo de Santa Catarina e Rio Grande do Sul para designar o peão menor de idade que não é de raça branca (HOUAISS; VILLAR, 2001). Ferreira (2004) traz como um brasileirismo para designar o índio jovem ou mestiço jovem de branco com índio; pequeno caboclo. Nessa mesma entrada, remete o usuário ao verbete "menino", tratando-se, pois, de um sinônimo. Em Santa Catarina e Rio Grande do Sul é uma variante usada para designar "qualquer menor que não é branco e trabalha como peão de estância" (FERREIRA, 2004), ou seja, a mesma acepção dada por Houaiss e Villar (2001).

Observa-se, assim, que as informações constantes dos dicionários ratificam a influência de fatores sociais e históricos na constituição do léxico português evidenciando, inclusive, os traços deixados pelos indígenas e africanos que, em conjunto com o elemento português, constituíram a base da sociedade brasileira.

\section{Materiais e métodos}

Os dados analisados foram coletados pela equipe do ALiB em 135 municípios brasileiros nas regiões Centro-Oeste, Sudeste e Sul. Em cada uma das unidades da Federação, foram selecionadas como pontos de inquéritos diferentes cidades, considerando-se a importância histórico-cultural da localidade e, também, a densidade demográfica do estado. Assim, o número de pontos linguísticos em cada unidade difere de uma para a outra. Em cada ponto, foram entrevistados quatro informantes de ambos os sexos com nível de escolaridade fundamental, ${ }^{2}$ perfazendo um total de 527 informantes. ${ }^{3}$ Desse modo, teve-se acesso aos dados relativos a nove localidades do estado do Mato Grosso; seis do Mato Grosso

\footnotetext{
2 Nas capitais somam-se, a esses quatro, informantes de nível superior. Este estudo não se atém à análise considerando as variáveis sociolinguísticas, pois o foco principal do trabalho é a distribuição diatópica.

3 Em função da abstenção de resposta, não constam dados de alguns informantes.
} 
do Sul; nove de Goiás; 17 municípios de Minas Gerais;4 38 de São Paulo; cinco localidades do Espírito Santo; nove do Rio de Janeiro; 17 municípios do Paraná; 10 localidades de Santa Catarina; e, por fim, 15 do Rio Grande do Sul. ${ }^{6}$

Para o armazenamento e análise dos dados coletados foi utilizado o software SPSS7 (Statistical Package for the Social Sciences) versão 17.0 (SPSS, 2008), o que possibilitou estabelecer as análises descritivas e inferenciais pertinentes ao estudo.

As variáveis numéricas, ou seja, o número de ocorrências de cada variante, foram expressas em média e desvio padrão. Quanto às variáveis categóricas, aqui representadas pelas variantes lexicais, foram utilizadas, para sumarizá-las, frequências simples e relativas (números e porcentagens) e intervalo de confiança de 95\%. Utilizou-se o teste estatístico de Kolmogorov-Smirnov (KS) para avaliar o pressuposto de normalidade, isto é, verificar a aderência das variáveis estudadas à distribuição de probabilidade normal. Valores de $\mathrm{p}$-valor ${ }^{8}$ maiores que 0,05 indicam que a variável tem adesão à distribuição normal. Para a comparação de médias entre grupos, necessária para os testes de hipóteses relativas às variáveis categóricas, foi considerada a adesão das variáveis à distribuição normal. Para tanto, utilizou-se o teste de Kruskall-Wallis para comparar mais que dois grupos independentes, no caso os estados e, em alguns casos, as mesorregiões desses estados. Os dados referentes a cada variante serão analisados segundo sua ocorrência. Os resultados são considerados estatisticamente significantes se p-valor $<0,05$.

\section{Análise dos dados}

\section{Contextualização da análise estatística}

A análise estatística dos resultados obtidos constitui um importante instrumento na validação desses dados. Resumidamente, o objetivo consiste em extrapolar os resultados da análise para a população estudada, neste caso,

\footnotetext{
4 Faz parte ainda da rede de pontos do ALiB mais seis localidades mineiras (Ipatinga, Ouro Preto, Viçosa, São João Del Rei, Muriaé e Juiz de Fora) cujos inquéritos não estavam finalizados na ocasião da elaboração deste trabalho, portanto, não fazem parte do corpus analisado.

5 Na ocasião da elaboração deste trabalho, a coleta de dados não havia sido concluída em cinco localidades fluminenses: São João da Barra, Campos dos Goytacazes, Três Rios, Nova Iguaçu e Parati, portanto, não fazem parte do corpus analisado..

6 Não constam do corpus os dados referentes a Osório e Santa Cruz do Sul.

7 Software de análise estatística amplamente utilizado em pesquisas experimentais aplicadas nas mais variadas áreas do conhecimento humano.

8 Valor estatístico utilizado para sintetizar o resultado de um teste de hipóteses.
} 
os informantes representativos do falar de cada região brasileira. Este trabalho apresenta alguns testes de hipóteses explorados visando a inferir conclusões sobre esta população. Na prática, os testes de hipóteses são utilizados para realizar inferências estatísticas. No caso das inferências, por meio do intervalo de confiança, busca-se delimitar o parâmetro populacional desconhecido. Assim, formula-se uma hipótese quanto ao valor do parâmetro e, com base nos elementos amostrais, aplica-se um teste que indicará a aceitação ou rejeição da hipótese formulada.

Em um teste de hipóteses, podem-se manipular duas categorias: hipótese nula e hipótese alternativa. A primeira refere-se à hipótese que se deseja provar como sendo verdadeira, ao passo que a segunda consiste na negação da primeira. O teste pode conduzir à aceitação ou à rejeição da hipótese nula, que corresponde, respectivamente, à negação ou à afirmação da hipótese alternativa. Neste âmbito, encontra-se aplicado o nível de significância de um teste, que consiste na probabilidade máxima de rejeitar a hipótese nula. Ou seja, o nível de significância de 5\% (amplamente utilizado em pesquisas experimentais) corresponde à probabilidade máxima de se rejeitar a hipótese nula quando, de fato, ela é verdadeira, caracterizando o erro tipo I (MAGALHÃES; LIMA, 2001).

No estudo, oito hipóteses foram testadas com base nos dados coletados: (1) as ocorrências das variantes das três regiões apresentam comportamento homogêneo; (2) a variante "menino" apresenta homogeneidade em sua distribuição nos dez estados; (3) a variante "moleque" apresenta distribuição homogênea na região Centro-Oeste; (4) a variante "guri" apresenta distribuição homogênea nos estados de Mato Grosso e Mato Grosso do Sul; (5) as variantes "moleque" e "garoto" apresentam homogeneidade no estado do Rio de Janeiro; (6) a variante "garoto" apresenta distribuição homogênea no estado de São Paulo; (7) a variante "guri" apresenta homogeneidade na região Sul; (8) a variante "piá" possui distribuição homogênea na região Sul.

\section{Tratamento dos dados}

Para a questão 132 do OSL foram documentados 960 registros, distribuídos em nove variantes lexicais, ${ }^{9}$ conforme se observa na Tabela 1.

9 Não foram consideradas as variantes que apresentaram ocorrência única no corpus: "mocinho", "bambino" e "bichinho". 
Tabela 1 - Distribuição geral das variantes lexicais para a questão 132 do OSL

\begin{tabular}{l|c|c}
\hline \multicolumn{1}{c|}{ Variantes } & $\mathbf{N}$ & \% total \\
\hline menino & 389 & 40,52 \\
\hline moleque & 181 & 18,85 \\
\hline guri & 153 & 15,94 \\
\hline garoto & 108 & 11,25 \\
\hline piá & 81 & 8,44 \\
\hline rapazinho & 20 & 2,08 \\
\hline pivete & 17 & 1,77 \\
\hline homenzinho & 7 & 0,73 \\
\hline pirralho & 4 & 0,42 \\
\hline total & 960 & \\
\hline
\end{tabular}

Fonte: Banco de dados do ALiB (2013).

A variante mais produtiva, no universo de todas as respostas, é "menino", que representa 40,52\% do corpus, seguida de "moleque" (18,85\%), "guri" (15,94\%), "garoto" (11,25\%), e "piá" (8,44\%). Em menor produtividade, encontramse "rapazinho" (2,08\%), "pivete" (1,77\%) e, com menos de um por cento de representatividade, foram documentadas as variantes "homenzinho" $(0,73 \%)$ e "pirralho" (0,42\%). A Figura 1 apresenta a produtividade dessas variantes por região administrativa.

"Menino" apresentou-se como a variante mais produtiva nas três regiões: Sudeste (48,13\%), Centro-Oeste (41,48\%) e Sul (29,48\%). No Centro-Oeste e no Sul, a segunda variante mais produtiva foi "guri" com 26,14\% e 27,05\%, respectivamente. A forma lexical "moleque" foi a segunda variante mais produtiva nos municípios da região Sudeste, representando $25,27 \%$ das respostas, seguindo-se da variante "garoto" (14,95\%). Essas formas ("moleque" e "garoto"), no Centro-Oeste, são as terceira e quarta mais produtivas, com 15,91\% de produtividade para "moleque" e 8,52\% para "garoto". Na Região Sul, por sua vez, destaca-se a variante "piá" $(21,58 \%)$ como a terceira mais representativa. As outras variantes pouco produtivas "rapazinho", "pivete" e "homenzinho" estiveram presentes nas três regiões com baixo índice de representatividade e a forma lexical "pirralho" ocorreu em algumas localidades do Centro-Oeste e do Sudeste, também com baixo índice percentual (0,57\% e 0,66\%, respectivamente). 
Figura 1 - Produtividade das variantes lexicais para a questão 132 do QSL segundo a região administrativa

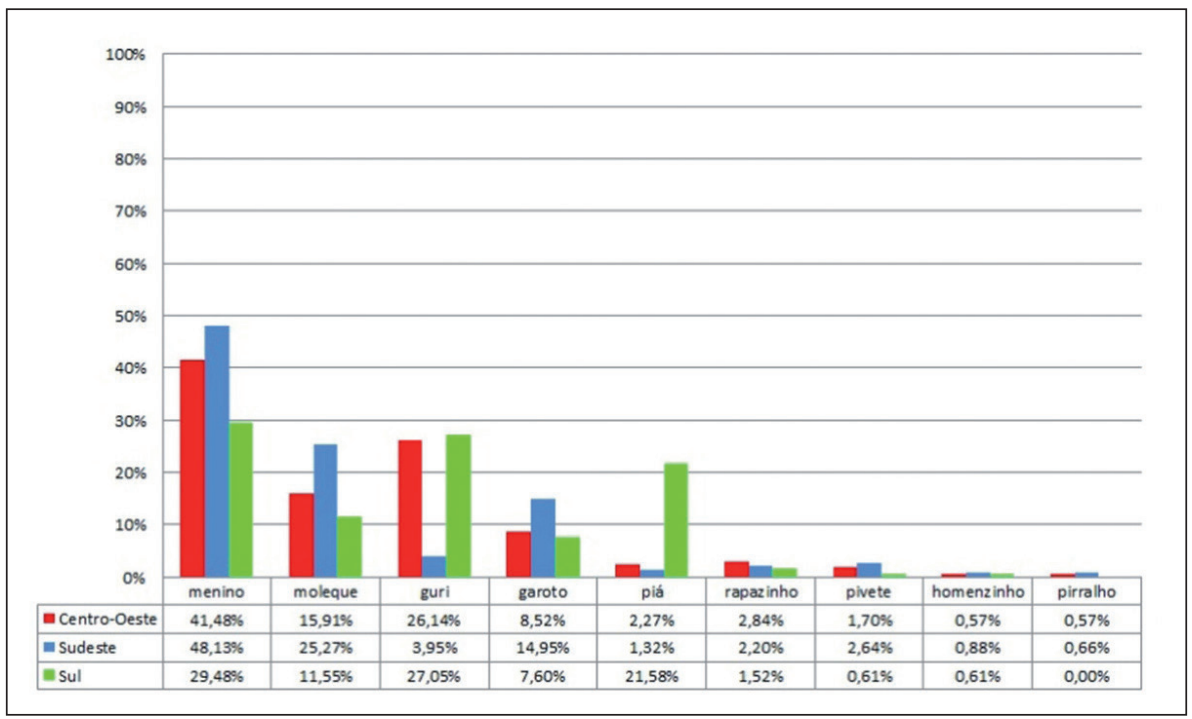

Fonte: Banco de dados do ALiB (2013).

Com vistas a facilitar a representação cartográfica e o tratamento estatístico dos dados, a análise apresentada no estudo se atém mais detalhadamente a cinco variantes mais produtivas: "menino", "moleque", "guri", "garoto" e "piá". Para o teste das hipóteses formuladas na pesquisa, fez-se necessário analisar o comportamento das referidas variantes caracterizadas como variáveis aleatórias dependentes em diferentes contextos. Para isso, foi utilizado o teste KS objetivando verificar se os dados apresentam aderência à distribuição de probabilidade normal. A Tabela 2 apresenta os resumos estatísticos segundo os grupos de regiões.

Tabela 2 - Resumo estatístico segundo a região administrativa

\begin{tabular}{ccccccc}
\hline & menino & moleque & guri & garoto & piá \\
\hline $\begin{array}{c}\text { Respostas: } \\
\text { média }\left(\boldsymbol{N}^{*}\right)\end{array}$ & $2,92(24)$ & $1,29(24)$ & $1,92(24)$ & $0,63(24)$ & $0,17(24)$ \\
\cline { 2 - 6 } $\begin{array}{c}\text { Centro- } \\
\text { Oeste }\end{array}$ & Desvio padrão & 1,176 & 0,955 & 1,640 & 0,576 & 0,381 \\
\cline { 2 - 7 } & $\mathbf{K S ~}(\mathbf{p}$-valor)** & $1,159(0,136)$ & $1,200(0,112)$ & $0,929(0,353)$ & $1,597(0,012)$ & $2,462(\mathrm{p}<0,001)$ \\
\hline
\end{tabular}




\begin{tabular}{|c|c|c|c|c|c|c|}
\hline & & menino & moleque & guri & garoto & piá \\
\hline & $\begin{array}{l}\text { Respostas: } \\
\text { média }\left(N^{*}\right)\end{array}$ & $3,16(69)$ & $1,70(69)$ & $0,26(69)$ & $0,99(69)$ & $0,09(69)$ \\
\hline \multirow[t]{3}{*}{ Sudeste } & Desvio padrão & 1,009 & 1,240 & 0,610 & 0,757 & 0,373 \\
\hline & $K S$ (p-valor) ${ }^{* *}$ & $2,412(p<0,001)$ & $1,465(0,027)$ & $3,963(p<0,001)$ & $2,284(p<0,001)$ & $4,437(p<0,001)$ \\
\hline & $\begin{array}{l}\text { Respostas: } \\
\text { média }\left(N^{*}\right)\end{array}$ & $2,31(42)$ & $0,90(42)$ & $2,12(42)$ & $0,60(42)$ & $1,69(42)$ \\
\hline \multirow[t]{2}{*}{ Sul } & Desvio padrão & 1,070 & 1,165 & 1,365 & 0,989 & 1,388 \\
\hline & $K S(p-\text { valor })^{* *}$ & $1,405(0,039)$ & $1,823(0,003)$ & $1,133(0,154)$ & $2,238(p<0,001)$ & $1,081(0,193)$ \\
\hline
\end{tabular}

Nota: ${ }^{*} \mathrm{~N}=$ Quantidade de localidades ${ }^{* *}$ Teste Kolmogorov-Smirnov

Fonte: Banco de dados do ALiB (2013).

Neste momento, é importante destacar que a distribuição normal é uma das mais importantes distribuições da estatística, sendo também conhecida como distribuição de Gauss ou Gaussiana, e possui grande uso na estatística inferencial.

A partir dos dados apresentados na Tabela 2, nota-se que, na região CentroOeste, as variantes "menino", "moleque" e "guri" apresentam aderência à distribuição normal (p-valor > 0,05). No Sul, apenas as variantes "guri" e "piá" apresentam o mesmo comportamento. Pode-se destacar, a partir dos dados, que na região Sudeste nenhuma variante adere à normal. Portanto, como nem todas as formas apresentam aderência a essa distribuição de probabilidade, considerase que os itens lexicais estudados não apresentam aderência à normal, sendo necessária a aplicação de testes estatísticos não paramétricos para testar as hipóteses formuladas no estudo. Vale ressaltar que a aplicação de testes não paramétricos ocorre quando a população dos dados a serem analisados não possui distribuição normal.

Outro aspecto importante a ser verificado diz respeito à análise de variância, que consiste na comparação de dois ou mais grupos em relação à localização. Para exemplificar, pode-se considerar a situação em que se pretende avaliar se três grupos apresentam desempenhos similares em uma determinada avaliação. A análise de variância procura responder a questões deste tipo por meio da comparação das localizações dos diferentes grupos. Esta comparação é feita a partir da dispersão presente no conjunto de dados (VIEIRA, 2006). 
Com o objetivo de verificar se as variâncias das ocorrências são homogêneas nas três regiões analisadas foi aplicado o teste de Kruskall-Wallis (Tabela 3). O resultado mostra que o teste alcançou um nível significativo, podendo-se assumir que as variâncias dos grupos não são homogêneas. A partir da análise de variância, nota-se que há diferença significativa entre as médias de todas as variantes ( $p$-valor $<0,05$ ). Assim, de acordo com os dados apresentados, concluise que as regiões não apresentam comportamento homogêneo e a hipótese nula 1 pode ser rejeitada.

Tabela 3 - Teste de homogeneidade das variantes com base nas regiões

\begin{tabular}{llllll}
\hline & $\begin{array}{c}\text { Centro- } \\
\text { Oeste }\end{array}$ & Sudeste & Sul & & \\
\cline { 2 - 4 } & $\begin{array}{l}\text { Média do } \\
\text { rank (N) }\end{array}$ & $\begin{array}{c}\text { Média do } \\
\text { rank (N) }\end{array}$ & $\begin{array}{c}\text { Média do } \\
\text { rank (N) }\end{array}$ & df & Teste*(p-valor) \\
\hline menino & $71,06(24)$ & $78,70(69)$ & $48,68(42)$ & 2 & $16,973(\mathrm{p}<0,001)$ \\
\hline moleque & $67,54(24)$ & $77,95(69)$ & $51,92(42)$ & 2 & $12,354(0,002)$ \\
\hline guri & $86,85(24)$ & $44,54(69)$ & $95,76(42)$ & 2 & $59,775(\mathrm{p}<0,001)$ \\
\hline garoto & $62,60(24)$ & $78,43(69)$ & $53,95(42)$ & 2 & $12,790(0,002)$ \\
\hline piá & $57,75(24)$ & $52,11(69)$ & $99,96(42)$ & 2 & $64,376(\mathrm{p}<0,001)$ \\
\hline
\end{tabular}

*Teste de Kruskall-Wallis N = quantidade de localidades

Fonte: Banco de dados do ALiB (2013).

Devido ao fato de "menino" ser a variante mais produtiva, presente em todos os estados, a próxima hipótese averiguada consistiu em verificar se a referida forma lexical apresenta distribuição homogênea nos dez estados considerando as mesorregiões contempladas pela rede de pontos. ${ }^{10}$ Novamente foi aplicado o teste de Kruskall-Wallis (Tabela 4).

10 Em Minas Gerais, três mesorregiões não são contempladas pela rede de pontos a que se teve acesso: Central Mineira, Zona da Mata e Vale do Rio Doce. No estado do Rio Grande do Sul, apenas a mesorregião Centro Oriental Rio-grandense não é contemplada. 
Tabela 4 - Análise de variância de menino nos estados

\begin{tabular}{|c|c|c|c|c|c|}
\hline Estados & & menino & Estados & & menino \\
\hline & $\chi^{2}$ & 3,758 & & $\chi^{2}$ & 3,500 \\
\hline \multirow[t]{3}{*}{ Mato Grosso } & $d f$ & 4 & Espírito Santo & $D f$ & 3 \\
\hline & $p$-valor $(N)$ & $0,440(9)$ & & $p$-valor (N) & $0,321(5)$ \\
\hline & $\chi^{2}$ & 2,333 & & $\chi^{2}$ & 6,621 \\
\hline \multirow{3}{*}{$\begin{array}{l}\text { Mato Grosso } \\
\text { do Sul }\end{array}$} & $d f$ & 3 & Rio de Janeiro & $D f$ & 5 \\
\hline & $p$-valor (N) & $0,506(6)$ & & $p$-valor (N) & $0,250(9)$ \\
\hline & $\chi^{2}$ & 5,472 & & $\chi^{2}$ & 8,963 \\
\hline \multirow[t]{3}{*}{ Goiás } & $d f$ & 4 & Paraná & $D f$ & 9 \\
\hline & $p$-valor $(N)$ & $0,242(9)$ & & $p$-valor (N) & 0,441 (17) \\
\hline & $\chi^{2}$ & 6,481 & & $\chi^{2}$ & 4,347 \\
\hline \multirow[t]{3}{*}{ Minas Gerais } & $d f$ & 8 & Santa Catarina & $D f$ & 4 \\
\hline & $p$-valor (N) & 0,593 (17) & & $p$-valor (N) & $0,361(10)$ \\
\hline & $\chi^{2}$ & 24,537 & & $\chi^{2}$ & 2,448 \\
\hline \multirow[t]{2}{*}{ São Paulo } & $d f$ & 15 & $\begin{array}{l}\text { Rio Grande } \\
\text { do Sul }\end{array}$ & $D f$ & 4 \\
\hline & $p$-valor $(N)$ & 0,057 (38) & & $p$-valor $(N)$ & $0,654(15)$ \\
\hline
\end{tabular}

*Teste de Kruskall-Wallis $\quad$ N = Quantidade de localidades

Fonte: Banco de dados do ALiB (2013).

Os resultados mostram que o teste não alcançou um nível significativo, podendo-se assumir que as variâncias dos estados são homogêneas. A partir da análise de variância (Tabela 5), nota-se que não há diferença significativa entre as médias da variante "menino" (p-valor > 0,05). Assim, de acordo com os dados apresentados, conclui-se que os estados apresentam comportamento homogêneo e a hipótese nula 2 pode ser aceita. A seguir, passa-se a apresentar os dados considerando individualmente cada uma das três regiões do país, bem como os estados que as constituem. 


\section{Região Centro-Oeste}

Dos 960 registros documentados no cômputo geral das ocorrências, 176 referem-se aos dados coletados nos municípios da região Centro-Oeste, distribuídos pelos três estados: Mato Grosso, Mato Grosso do Sul e Goiás. Em cada um desses estados, as variantes lexicais obtiveram diferentes índices de ocorrência. Em dados percentuais, apresenta-se a distribuição visualizada na Figura 2.

Figura 2 - Produtividade das variantes lexicais para a questão 132 do QSL nos estados da região Centro-Oeste

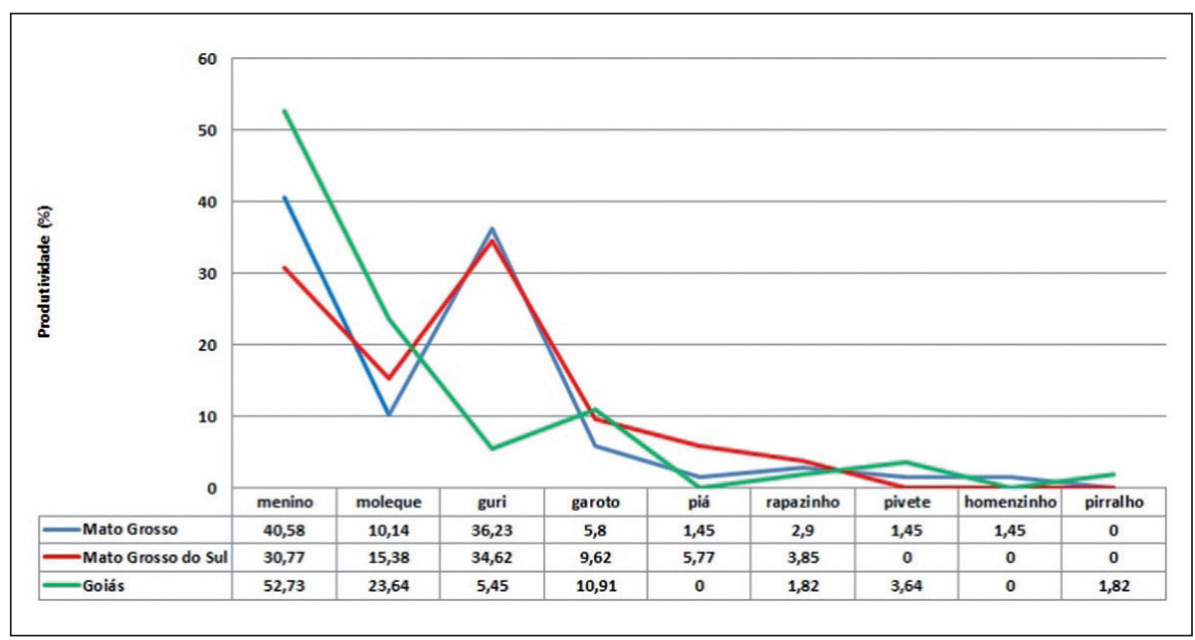

Fonte: Banco de dados do ALiB (2013).

Observa-se que a variante "menino" predominou nos três estados, obtendo maior produtividade em Goiás (52,73\%). A variante "moleque" também foi mais produtiva nesse estado (23,64\%), ao passo que "guri" não foi tão significativa $(5,45 \%)$ se comparada com a produtividade dessa variante em Mato Grosso (36,23\%) e Mato Grosso do Sul (34,62\%), que apresentaram índices percentuais próximos.

Com exceção do ponto 105 (Diamantino-MT), a variante "menino" esteve presente em todas as outras 23 localidades que compõem essa região. Assim, para a representação cartográfica, essa variante foi desconsiderada por apresentar uma distribuição diatópica homogênea na região Centro-Oeste. A Figura 3 mostra a distribuição diatópica de quatro variantes lexicais, a saber: "moleque", "guri", "garoto" e "piá". 
Os dados da carta linguística (Figura 3) ratificam as informações constantes da Figura 2, ou seja, há uma continuidade na distribuição diatópica da variante "guri" na rede de pontos do Mato Grosso e do Mato Gosso do Sul (ocorrência em todos os pontos), adentrando apenas duas localidades goianas, ponto 124 (Jataí) e ponto 125 (Catalão), localizadas na Mesorregião do Sul Goiano. Ou seja, a forma lexical "guri" não esteve presente em sete das nove localidades que compõem a rede de pontos em Goiás, que, por sua vez, apresenta uma distribuição uniforme da variante "moleque", pois há registros dessa variante em todas as localidades selecionadas. Nesse sentido, a terceira hipótese do estudo consistiu em averiguar se "moleque" apresenta homogeneidade em sua distribuição na região CentroOeste. Os dados obtidos pelo teste de Kruskal-Wallis revelam que a hipótese nula 3 pode ser aceita $\left(\chi^{2}=1,082 ; d f=2 ; p\right.$-valor $\left.=0,582\right)$.

Figura 3 - Distribuição diatópica das quatro variantes lexicais mais produtivas na rede de pontos da região Centro-Oeste

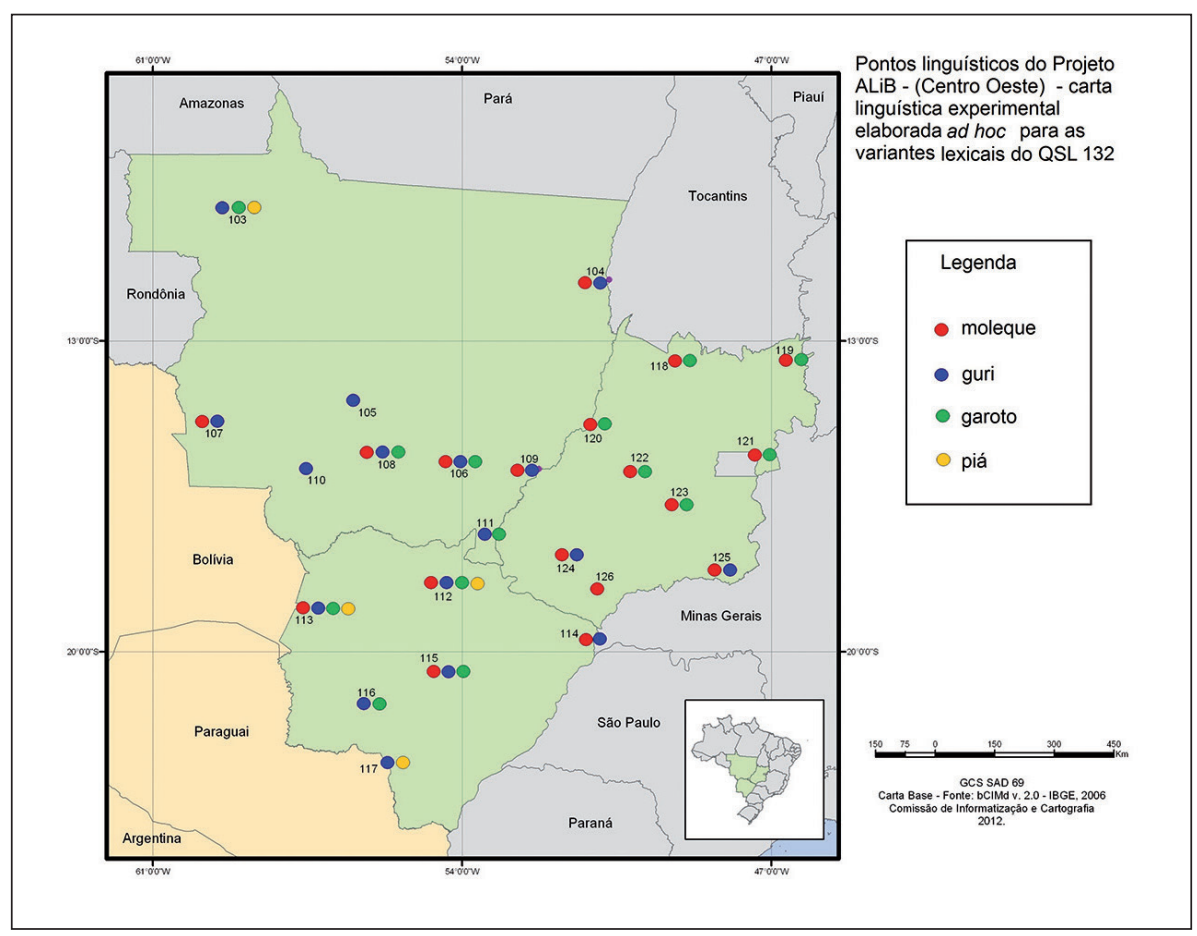

Fonte: Banco de dados do ALiB (2013).

A continuidade na distribuição diatópica de "guri" nos estados de Mato Grosso e Mato Grosso do Sul é corroborada pelos resultados oriundos do teste de 
Kruskal-Wallis ( $\mathrm{p}$-valor = 0,271 em MT e p-valor = 0,407 em MS) quando aplicado nos dados dos referidos estados. Dessa forma, a hipótese nula 4 pode ser aceita, ou seja, "guri" apresenta distribuição homogênea nos estados de Mato Grosso e Mato Grosso do Sul.

A variante "moleque" adentra cinco pontos linguísticos do estado do Mato Grosso: dois localizados na Mesorregião do Nordeste Mato-grossense (ponto 104 - São Félix do Araguaia e ponto 109 - Barra do Garças), no Centro Sul Matogrossense (ponto 108 - Cuiabá), na Mesorregião do Sudeste Mato-grossense (ponto 106 - Poxoréu) e no Sudoeste Mato-grossense (ponto 107 - Bela Vista da Santíssima Trindade). Essa variante expande-se também pelo Mato Grosso do Sul em quatro localidades: duas na Mesorregião do Centro Norte do Mato Grosso do Sul (ponto 112 - Coxim e 115 - Campo Grande), uma na região dos Pantanais Sul Mato-grossenses (ponto 113 - Corumbá) e ocorre em um ponto do leste do Mato Grosso do Sul (ponto 114 - Paranaíba). Observa-se, ainda, que há a predominância da variante "garoto" nos estados de Goiás e Mato Grosso do Sul, pois ocorreu na maioria dos pontos linguísticos desses estados e está registrada em apenas quatro das nove localidades do estado do Mato Grosso. A variante "piá", por sua vez, não foi documentada em Goiás, registrada em três localidades sul-matogrossenses e em apenas uma localidade do Mato Grosso.

Portanto, os dados apontam que na região Centro-Oeste não é possível traçar uma área de isoléxica para quatro variantes:

(i) Para "menino", pois apresenta distribuição homogênea em todo o território.

(ii) Para "moleque", porque, apesar de concentrar maior distribuição em Goiás, os dados demonstram que não há uma distribuição contínua dessa variante nos outros estados.

(iii) Para "garoto", pois apresenta uma distribuição irregular, ou seja, não há uma continuidade dessa variante no território, ocorrendo também isoladamente no norte do Mato Grosso (ponto 103 - Aripuanã).

(iv) Para "piá", pois está registrada em duas localidades ao norte (pontos 112 - Coxim e 113 - Corumbá), uma ao sul do Mato Grosso do Sul (ponto 117 - Ponta Porã) e em apenas uma localidade ao norte do Mato Grosso (Aripuanã), portanto, em uma faixa territorial descontínua. Além disso, os relatos de alguns informantes indicam que se trata de uma variante de caráter diatópico, referente ao estado do Paraná. Apesar de uma informante do sexo feminino pertencente à primeira faixa etária (18-30 anos) do ponto 103 - Aripuanã - afirmar veementemente que usa a variante "piá" em seu idioleto, ${ }^{11}$ há o registro na fala de um informante dessa

11 Por idioleto entende-se: "[...] conjunto de usos de uma língua própria de um indivíduo, num momento determinado." (DUBOIS et al, 1991, p.329). 
mesma localidade de que a variante "piá" tem um caráter diatópico, ou seja, pertence a outra região, neste caso, ao estado do Paraná, conforme se observa no discurso transcrito ipsis litteris, a seguir: ${ }^{12}$

INF.- Ah, nóis já chama ele de Maciel: "oh Macielzinho vem cá” ele já cresceu... ((referindo-se ao neto))

INQ.- É, mas e se o senhor não sabe o nome dele, na rua...

INF.- Ah, não nói chamamo... éh... na nossa, na nossa linguage, nóis chamava assim: "oh minino, vem cá", né, nóis chamava ‘ôh minino' [mi’ninu] vem cá. Já na língua do pessoal aqui, daqui pra frente principalmente da região do Paraná chama piá né: " ôh piá [pi’a] vem cá".

INQ.- Mas aqui é menino?

INF.- Aqui é menino, na nossa tredição...(?=tradição).

Por outro lado, a distribuição diatópica da variante "guri", conforme já observado, permite o traçado de uma área de isoléxica que contempla todo o estado do Mato Grosso e Mato Grosso do Sul adentrando ao sul do estado de Goiás, o que revela, portanto, uma diferença linguística entre Goiás e os outros estados que compõem essa região. Essa diferença linguística é evidenciada, inclusive, no discurso dos informantes, conforme se observa no trecho transcrito relativo à fala de um informante ${ }^{13}$ de Goiânia (ponto 123):

INQ.- O senhor chama assim: "Ô criança, venha pra cá?", se for do sexo masculino?

INF.- Minino [mi’ninu], assim num tem né...

INQ.- Menino?

INF.- É.

INQ.- Conhece por algum outro nome?

INF.- Parece que no Mato Grosso fala guri [gu'ri] né.

INQ. - É?

INF.- $\underline{\underline{E}}$, o guri. Chama de guri.

INO. - Aqui fala guri?

INF.- Não, aqui num chama de guri não, já vi falá em guri éh... no Mato Grosso, que eu tenho uma cumade lá e a gente ía pra lá, ela chamava os minino dela de guri.

INQ. - Aqui não?

INF.- Aqui num... nunca vi falá não.

12 Transcrição grafemática e fonética. As siglas INQ. e INF. indicam os turnos da conversação do inquiridor e do informante, respectivamente. Esse trecho refere-se ao discurso do informante 3 de Aripuanã - ponto 103 (homem pertencente à segunda faixa etária - 50 a 65 anos - com ensino fundamental).

13 Homem, pertencente à segunda faixa etária (50 a 65 anos), com ensino fundamental. Os trechos sublinhados indicam sobreposição das vozes. 
Por fim, ainda no Centro-Oeste, das 176 ocorrências documentadas, 10 delas referem-se a quatro variantes menos produtivas, a saber: "rapazinho" (cinco registros), "pivete" (três registros) e "homenzinho" e "pirralho" como ocorrências únicas. Essas formas lexicais ocorreram esparsamente por todo o território: "rapazinho" esteve presente nos pontos 111 - Alto Araguaia-MT, 114 - ParanaíbaMS e 120 - Aruanã-GO. A variante "pivete" foi documentada nos pontos 121 Formosa-GO, 132 - Goiânia-GO e 108 - Cuiabá-MT. As ocorrências únicas do Centro-Oeste foram documentadas no ponto 103 -Aripuanã-MT ("homenzinho") e em Formosa-GO, ponto 121 ("pirralho").

\section{Região Sudeste}

Nos municípios da região Sudeste, foram documentados 455 registros com diferentes índices de ocorrências. Em dados percentuais, apresenta-se a produtividade dessas ocorrências por meio da Figura 4.

Este gráfico revela um comportamento semelhante das variantes em cada um dos quatro estados que compõem a região. Assim, pode-se apontar três pontos principais: (i) a predominância da variante "menino" nos quatro estados, com produtividade acima de 50\% em três deles: Rio de Janeiro (63,64\%), Espírito Santo (60\%) e Minas Gerais (52,59\%); (ii) a baixa produtividade da variante "guri" em três estados: São Paulo (4,63\%), Espírito Santo (4\%) e Minas Gerais (3,45\%), não ocorrendo nos municípios do Rio de Janeiro; (iii) a presença da variante "garoto" com percentual próximo em Minas Gerais (18,97\%), Rio de Janeiro (18,18\%) e diferentes índices no Espírito Santo (16\%) e São Paulo (12,81\%).

Figura 4 - Produtividade das variantes lexicais para a questão 132 do OSL nos estados da região Sudeste

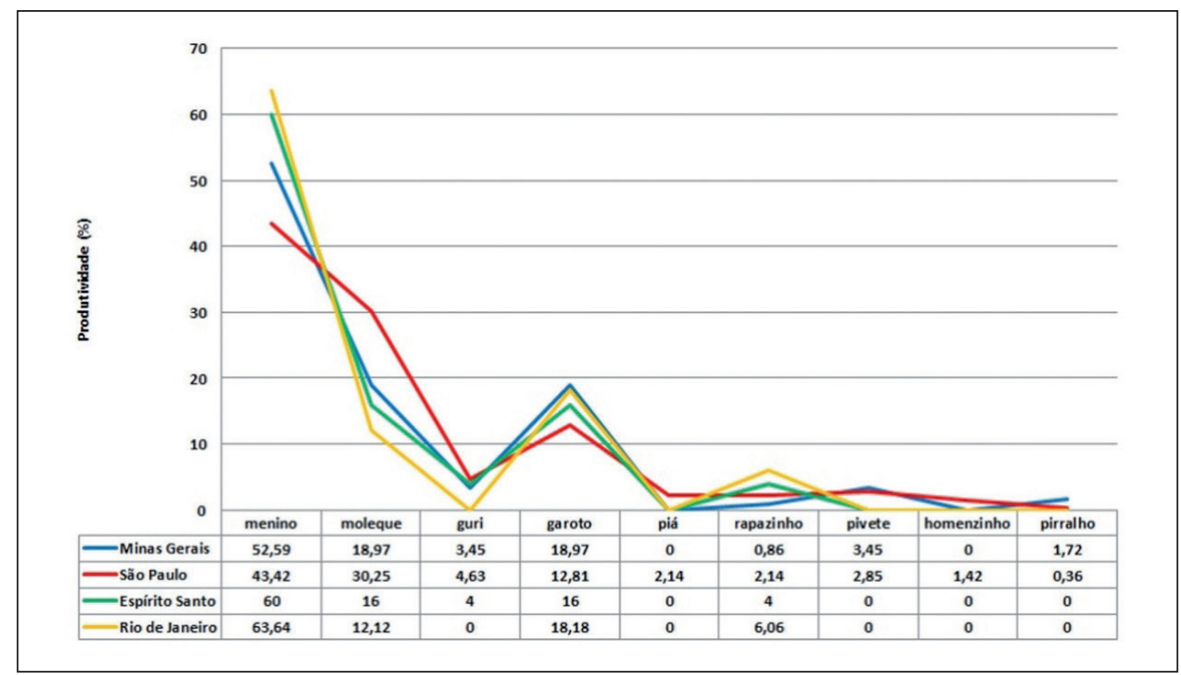

Fonte: Banco de dados do ALiB (2013). 
Assim como no Centro-Oeste, no Sudeste a variante "menino" também ocorreu em todos os pontos linguísticos. Dessa forma, para a cartografia, essa forma lexical foi desconsiderada, haja vista que a sua distribuição diatópica é homogênea em toda a região. A Figura 5 apresenta a distribuição das quatro variantes ("moleque", "guri", "garoto", "piá") nos pontos linguísticos do Sudeste.

Figura 5 - Distribuição diatópica das quatro variantes lexicais mais produtivas na rede de pontos da região Sudeste

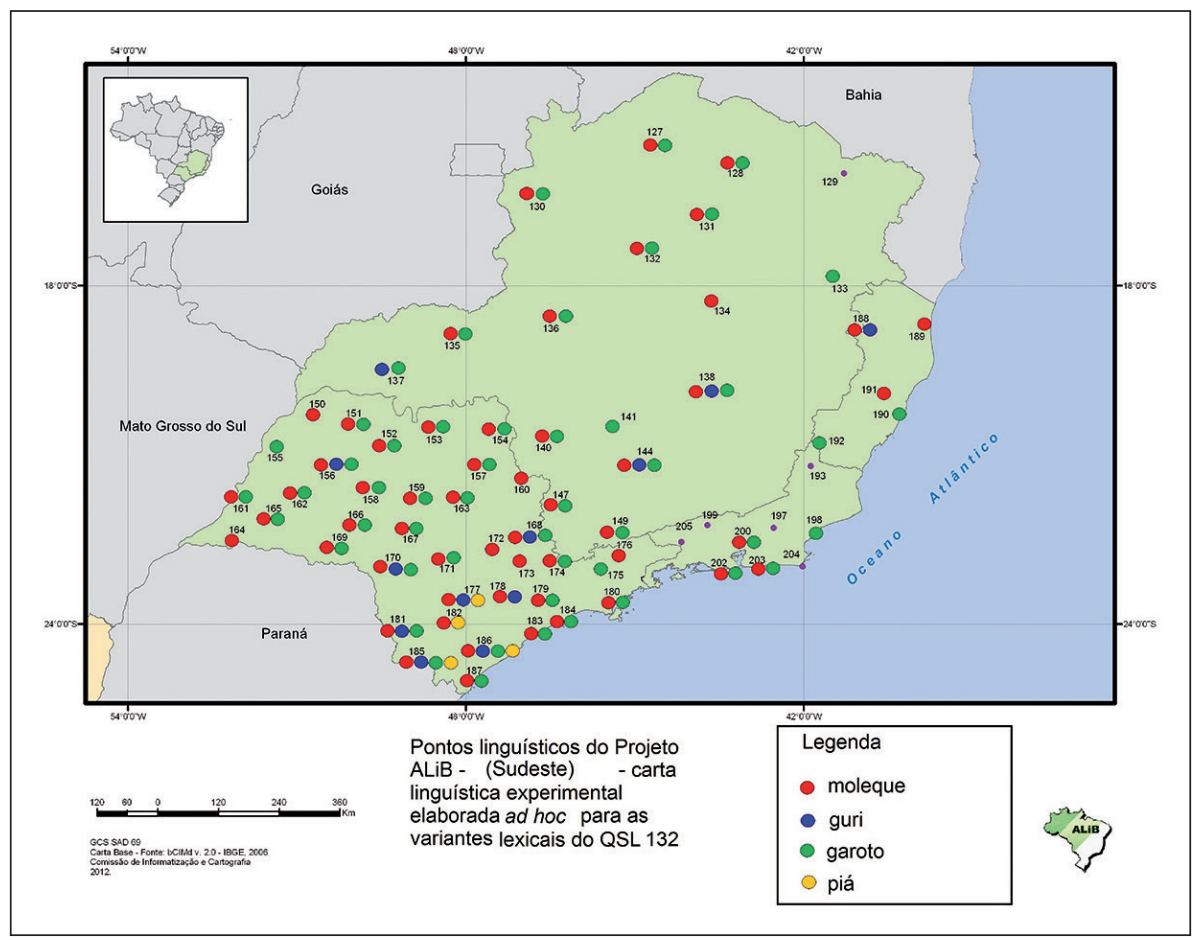

Fonte: Banco de dados do ALiB (2013).

A princípio, observa-se que, no mapa, há seis pontos linguísticos em que não ocorre nenhuma das quatro variantes elencadas na legenda (ponto 129 Pedra Azul/MG, 193 - Itaperuna/RJ, 197 - Nova Friburgo/RJ, 199 - Valença/RJ, 204 - Arraial do Cabo/RJ e ponto 205 - Barra Mansa/RJ). Isso se deve ao fato de que, nesses pontos, houve a ocorrência quase que exclusiva da variante mais produtiva do corpus, "menino", pois, nos pontos 197 e 204, além de "menino" ocorreu também uma variante menos produtiva, "rapazinho".

Dentre as quatro variantes escolhidas para representação cartográfica, destaca-se a forma lexical "moleque", que apresenta uma distribuição mais 
uniforme no estado de São Paulo, em comparação aos outros estados, pois dos 38 pontos linguísticos que compõem a rede de pontos em São Paulo, apenas em dois deles essa variante não ocorreu (ponto 155 - Andradina, ao noroeste, e no ponto 175 - Taubaté, situado a leste). Em Minas Gerais, dos 17 pontos a que se teve acesso, em quatro deles não há a ocorrência da variante "moleque", a saber: ponto 137 - Campina Verde, localizado no Triângulo Mineiro; 141 - Formiga, situado ao sul do estado e em dois municípios localizados no nordeste mineiro, 129 - Pedra Azul, e ponto 133 - Teófilo Otoni. No Espírito Santo, a variante "moleque" não ocorreu na capital - Vitória, ponto 190, e no ponto 192 - Guaçuí, divisa política com os estados do Rio de Janeiro e Minas Gerais. Por fim, no Rio de Janeiro, a produtividade da variante "moleque" foi baixa $(12,12 \%)$, conforme atestam os dados da Figura 4, e esteve presente apenas em três dos nove municípios a que se teve acesso. Essa variante figurou na capital - Rio de Janeiro (ponto 202) e nos pontos 200 - Petrópolis e 203 - Niterói. Essa disparidade em relação aos outros estados deve-se ao fato de, no Rio de Janeiro, predominar o uso da variante "menino" com representatividade de $63,64 \%$ das respostas, conforme se verifica na Figura 4. Apesar disso, o teste de homogeneidade de variâncias indicou que a hipótese 5 pode ser aceita $\left(\chi^{2}=7,714 ; \mathrm{df}=5 ; \mathrm{p}\right.$-valor $\left.=0,173\right)$, ou seja, os resultados do teste evidenciam a homogeneidade da distribuição das variantes "moleque" na rede de pontos a que se teve acesso. Porém, vale ressaltar que a coleta de dados nesse estado ainda não foi concluída pela equipe do Projeto ALiB, portanto, tal hipótese se aplica aos dados analisados e sua possível generalização dependerá do corpus completo do estado do Rio de Janeiro.

Assim, pode-se afirmar que, embora se verifique no mapa (Figura 5) uma continuidade da distribuição diatópica da variante "moleque" (desde o estado de São Paulo adentrando ao Triângulo Mineiro, centro de Minas Gerais até o Norte do Espírito Santo), não é possível traçar uma linha de isoléxica. Em virtude da ausência dos dados referentes a seis localidades mineiras e cinco localidades fluminenses, ${ }^{14}$ não é possível verificar se essa variante está documentada nas localidades do sul e leste de Minas Gerais, bem como nas demais cidades do Rio de Janeiro que integram a rede pontos do Projeto AliB nos referidos estados.

O uso da variante "moleque" esteve atrelado ao caráter ofensivo para se referir à criança dependendo do contexto; portanto, em algumas situações há a preferência pela variante "moleque" em detrimento de "menino", conforme se observa no discurso de alguns informantes como os reproduzidos a seguir:

14 Na ocasião da elaboração deste trabalho, a equipe do Projeto ALiB não havia concluído a coleta de dados nos pontos 139 - Ipatinga, 142 - Ouro Preto, 143 - Viçosa, 145 - São João Del Rei, 146 - Muriaé, 148 - Juiz de Fora, do estado de Minas Gerais, e nos pontos 194 - São João da Barra, 195 - Campo de Goytacazes, 196 - Três Rios, 201 - Nova Iguaçu e 206 - Parati, no estado do Rio de Janeiro. 
INF.- Minino [mi’ninu].

INQ. - Tem outro nome pra menino, aqui?

INF.- Tem. Muleque [mu'leki], pivete [pi'vet fr]. Depende do estado da criança. Se a gente vê que é minino, a gente fala que é minino, né, mai' se a gente vê que é mai' crescidin, aí já... pivete, é muleque.

INQ.- Chamar uma criança de moleque, isso é ofensivo?

INF.- Ah, pra mim sei lá né, é falta de educação né, criança, criança é criança.

INQ. - Se você por exemplo tivesse um filho e falar "eu tenho um moleque lá em casa".

INF.- Ai já não. Depende do lugar né, depende da hora, você não vai sair na rua e chamar o minino de muleque, né, daí tem o pai do menino, o pai vai vim querê tirá satisfação, daí já tá ofendendo. ${ }^{15}$

INQ.- Tem outro nome pra menino?

INF.- Muleque [mu'lekı].

INO.- Moleque é ofensivo? Se você falar assim: "Eu tenho dois moleques". É ofensivo?

INF.- Eu num acho.

INQ.- Não né, não ofende. "Eu tenho dois moleques."

INF.- É, sem maldade nenhuma.

INQ.- Como que é com maldade?

INF.- Por exemplo, "eu tenho dois muleques", eh... daí "cê fala, sem maldade, aí com maldade "cê fala... eh... por exemplo: "Aquele dois muleque não qué sabê de nada",((tom de voz mais alto)), aí já é uma ofensi... uma ofensa, né.

INQ.- Às vezes você fala para o teu namorado: "Você parece um moleque". Aí é ofensivo, né?

INF.- É. ${ }^{16}$

A variante "guri", por sua vez, obteve baixa produtividade no Sudeste, registrada em 12 municípios, dos quais oito são paulistas, localizados em diferentes regiões do estado como, por exemplo, no ponto 156 - Araçatuba - ao noroeste, nos ponto 170 - Bernardino de Campos e 181 - Itararé - no sudoeste do estado, em dois municípios localizados no Vale do Ribeira, pontos 185 - Ribeira e 187 Registro, nos pontos 177 e 178, Itapetininga e Sorocaba, e no ponto 168 - Mogi Mirim, localizado no nordeste paulista. Já no estado de Minas Gerais, são três os municípios em que a variante "guri" foi documentada: ponto 137 - Campina Verde, localizado no Triângulo Mineiro; ponto 144 - Lavras, ao sul do estado; e na

15 Trecho do inquérito 135/1 - Uberlândia/MG. Informante do sexo masculino, de 18 a 30 anos com ensino fundamental de escolaridade.

16 Trecho do inquérito 176/2 - Guaratinguetá/SP. Informante do sexo feminino, de 18 a 30 anos, com ensino fundamental de escolaridade. 
capital, Belo Horizonte, ponto 138. Por fim, no Espírito Santo, essa variante ocorreu somente em Barra de São Francisco - ponto 188, localizado na fronteira política do estado do Espírito Santo com Minas Gerais, no norte do estado.

Assim, pode-se inferir que não é possível traçar uma linha de isoléxica para essa variante na região Sudeste, pois sua distribuição espacial não apresenta uma concentração específica em determinada área. Porém, a presença da variante "guri" em determinadas localidades paulistas, tais como Itararé, Itapetininga e Sorocaba, pode ser explicada pela influência vinda do sul do país, haja vista que algumas dessas localidades eram pontos pertencentes à antiga rota proveniente do Caminho das Tropas, pela consequência do Tropeirismo no Paraná. ${ }^{17}$

A terceira variante mais produtiva no Sudeste ("garoto") encontra-se registrada na grande maioria dos pontos linguísticos do estado de São Paulo, não ocorrendo no ponto 150 - Jales, ao noroeste, e no ponto 164 - Teodoro Sampaio, além de ocorrer em uma faixa territorial que vai desde o ponto 160 - Mococa, localizado no nordeste paulista até o ponto 182 - Capão Bonito, situado ao sul do estado, conforme se observa na Figura 6.

Figura 6 - Isoléxica da variante garoto nas localidades do estado de São Paulo

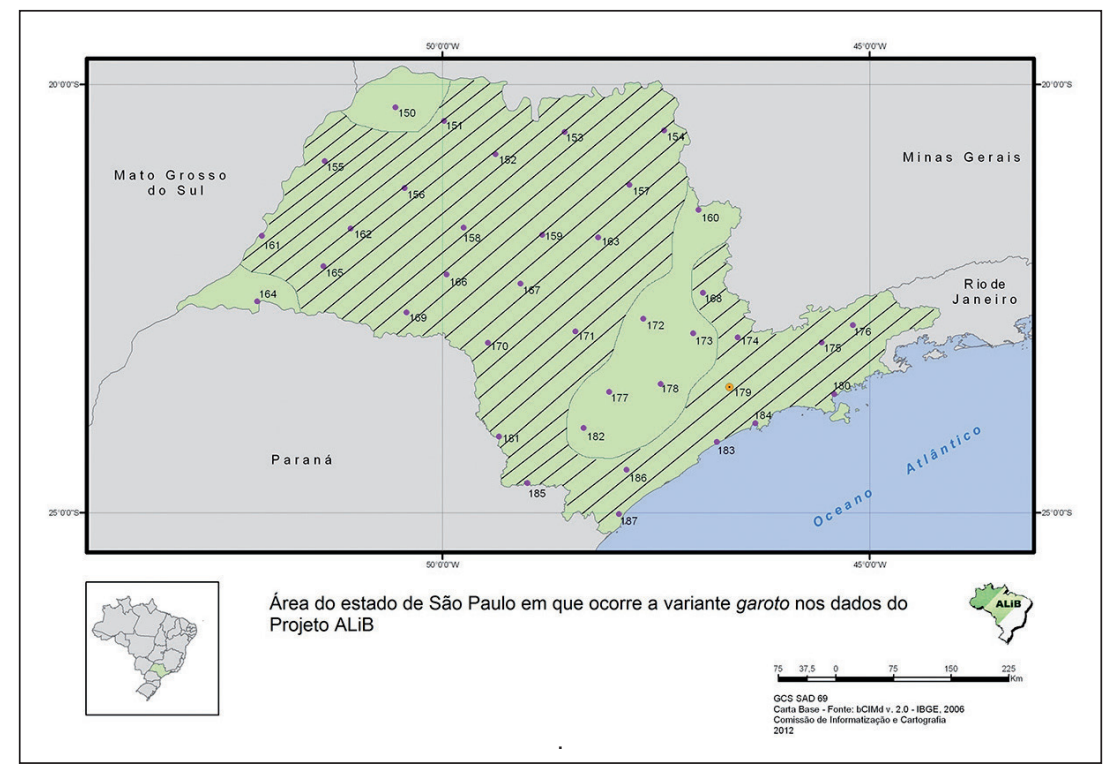

Fonte: Banco de dados do ALiB (2013).

17 O chamado Caminho das Tropas consistiu em uma antiga via terrestre de acesso ao Rio Grande do Sul, na época do Brasil colônia usado principalmente para o transporte de muares. O Caminho do Viamão era o mais utilizado, partia de Viamão/RS e atravessava os campos do Paraná adentrando ao estado de São Paulo passando por Itararé, Itapetininga até o destino final, Sorocaba. 
Portanto, dos 38 municípios paulistas, em apenas oito deles essa variante não foi documentada ou não foi reconhecida pelos informantes como uma forma típica para denominar a criança do sexo masculino na localidade. A ocorrência dessa variante, no território paulista, portanto, apresenta uma distribuição homogênea evidenciada pela aplicação do teste de Kruskal-Wallis $\left(\chi^{2}=7,377\right.$; $\mathrm{df}=15$; $\mathrm{p}$-valor $=0,946$ ) e a hipótese 6 pode ser aceita .

Em Minas Gerais, a variante "garoto" não esteve presente em apenas dois pontos linguísticos: ponto 129 - Pedra Azul, no nordeste mineiro, em que a variante exclusiva foi "menino", e no ponto 134 - Diamantina, localizado no centro do estado, em que houve a ocorrência das variantes "menino" e "moleque". No Espírito Santo, essa variante circunscreve-se a duas localidades: na capital - ponto 190 (Vitória) e na fronteira com Minas e Rio de Janeiro - ponto 192 - Guaçuí. Portanto, não há registro da variante "garoto" em dois municípios capixabas localizados ao norte, pontos 188 e 189 - Barra do São Francisco e São Mateus, e também em um município da região central do estado - ponto 191 - Santa Teresa. No Rio de Janeiro, por sua vez, dos nove pontos a que se teve acesso, em quatro deles essa variante foi documentada, a saber: pontos 198 - Macaé, 200 - Petrópolis, 202 - Rio de Janeiro e 203 - Niterói. Novamente, foi aplicado o teste de KruskalWallis para verificar a homogeneidade de "garoto" no estado do Rio de Janeiro. O resultado mostra que a variante apresenta distribuição homogênea $\left(\chi^{2}=7,556\right.$; $\mathrm{df}=5$; $\mathrm{p}$-valor $=0,182)$ e a hipótese nula 5 pode ser aceita .

Por fim, a variante "piá" não apresentou uma distribuição diatópica uniforme nos estados que compõem a região Sudeste. O único estado em que ocorre essa variante é São Paulo, presente nos pontos 177 - Itapetininga, 182 - Capão Bonito, 185 - Ribeira e 186 - Registro, ou seja, a forma lexical piá restringe-se a uma área específica do estado, podendo, de certa forma, indicar uma área de isoléxica (Figura 7). A presença dessa variante nessas localidades possivelmente justifica-se porque alguns desses municípios pertenciam ao Caminho dos Tropeiros, assim como foi afirmado acerca da variante "guri". 
Figura 7 - Isoléxica da variante piá nas localidades do estado de São Paulo

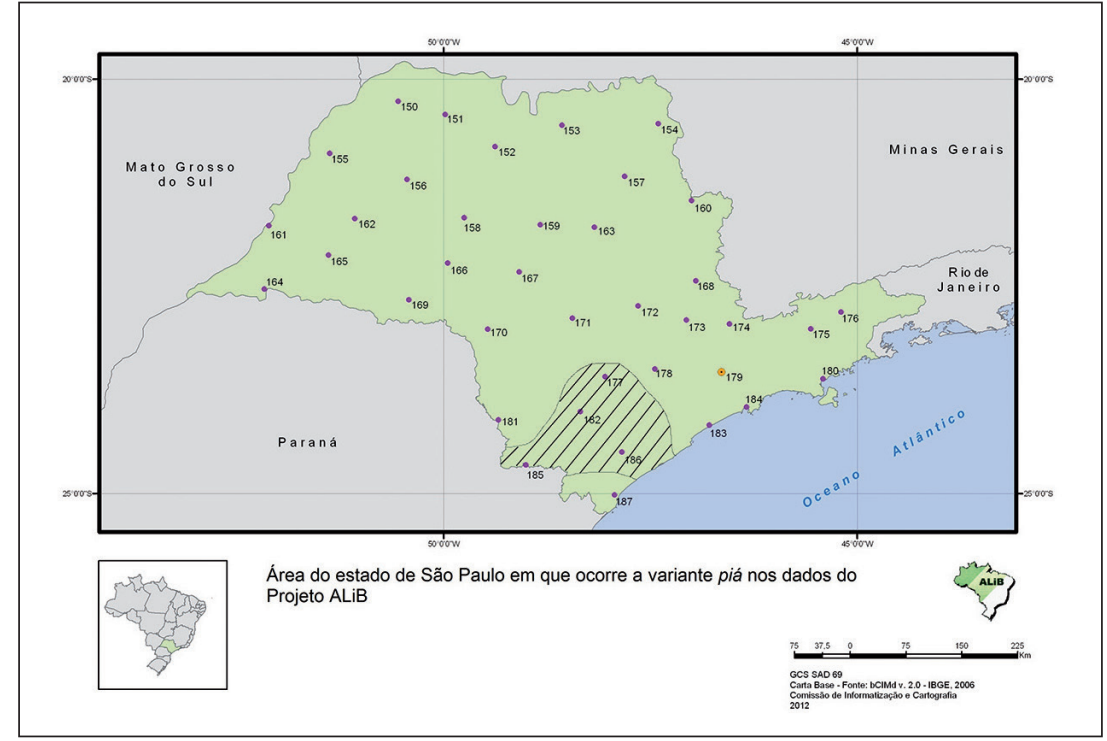

Fonte: Banco de dados do ALiB (2013).

Ainda no Sudeste, foram registradas outras quatro variantes menos produtivas, distribuídas esparsamente por todos os estados da região. Assim, foram documentadas 12 ocorrências da variante "pivete" das quais oito foram em cidades paulistas, e quatro em municípios de Minas Gerais. O uso dessa variante, geralmente, está associado ao caráter ofensivo que lhe é atribuído para se referir à criança, conforme se observa no discurso de uma informante transcrito a seguir:

INQ.- Pra menino, pode dar um outro nome?

INF.- Moleque [mo'leks].

INQ.- Que mais?

INF.- Hum, pivete [pi’vet $\left.\int_{I}\right]$.

INQ. - É ofensivo?

INF.- Pivete é.

INQ.- E moleque?

INF.- Moleque também eu acho que é.

INQ.- Você, por exemplo, se você tivesse um, "ah eu tenho um molequinho lá em casa." Isso é ofensivo? 
INF.- Ah, dependendo da forma que fala não, se você fala assim: Ah eu tenho um molequinho lá em casa, e se você fala: O moleque sai daí, já tô ofendendo, são as formas de falá. ${ }^{18}$

A variante "rapazinho", por sua vez, não recebe esse caráter ofensivo; foi registrada no corpus do Sudeste com 11 ocorrências: uma em Minas, um registro no estado do Espírito Santo, um no Rio de Janeiro e oito ocorrências no estado de São Paulo. Foram documentadas quatro ocorrências para "homenzinho" no estado de São Paulo e, por fim, três ocorrências para "pirralho", das quais duas em São Paulo e uma em Minas Gerais.

\section{Região Sul}

No Sul do Brasil, foram documentados 329 registros com diferentes índices de representatividade para cada uma das variantes. Assim, destacam-se três variantes principais, dependendo do estado, conforme se observa na Figura 8.

Figura 8 - Produtividade das variantes lexicais para a questão 132 do QSL nos estados da região Sul

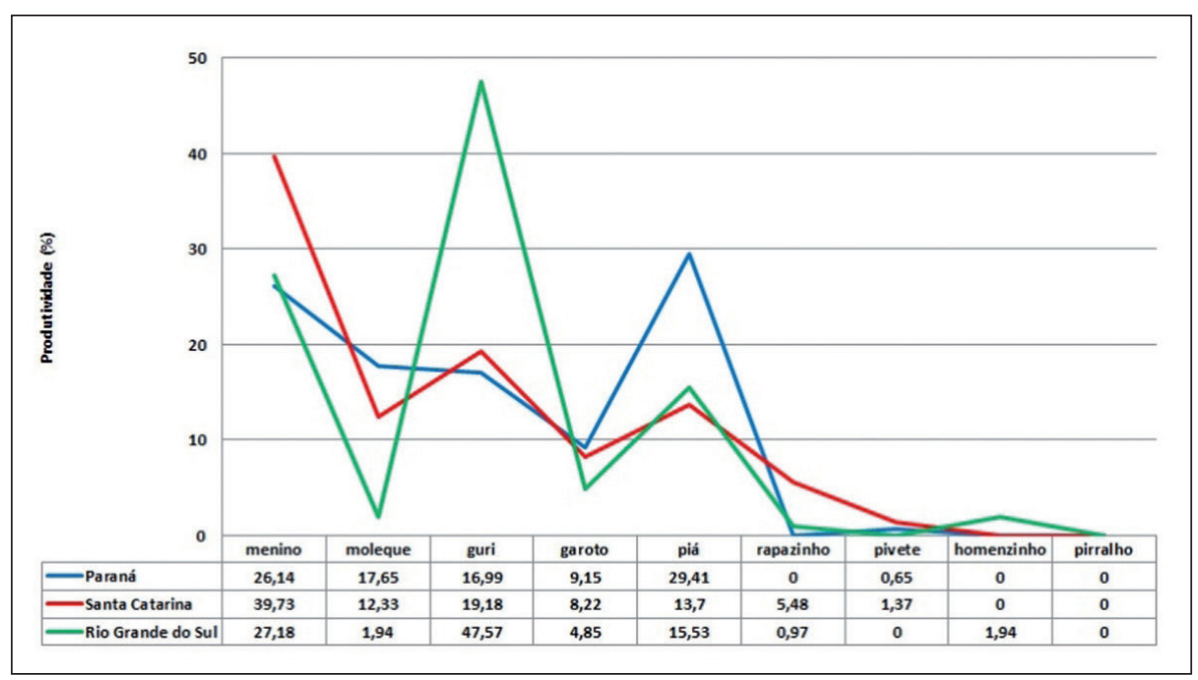

Fonte: Banco de dados do ALiB (2013).

18 Trecho do inquérito 137/2 - Campina Verde/MG. Informante do sexo feminino, de 18 a 30 anos, com ensino fundamental de escolaridade. 
Contrariamente ao que ocorreu no Sudeste, a variante "menino" não predominou em todos os estados que compõem a região Sul, pois essa forma lexical obteve maior produtividade no estado de Santa Catarina (39,73\%), enquanto, no Rio Grande do Sul, "guri" se apresentou como a forma majoritária (47,57\%), ao passo que, no estado do Paraná, "piá" obteve maior índice de representatividade $(29,41 \%)$. Observa-se também neste estado que a segunda e a terceira variantes mais produtivas foram "menino" (26,14\%) e "moleque" (17,65\%). A forma "guri" apresentou-se como a quarta variante mais produtiva nas cidades paranaenses $(16,99 \%)$.

Em Santa Catarina, figuraram como segunda e terceira mais produtivas as formas lexicais "guri" (19,18\%) e "piá" (13,7\%). A quarta variante mais produtiva foi "moleque" (12,33\%). Já, no Rio Grande do Sul, a segunda e a terceira variantes com mais representatividade foram "menino" (27,18\%) e "piá" (15,53\%). A variante "garoto", nas localidades gaúchas, apresenta-se como a quarta variante, porém com baixo índice de representatividade (4,85\%). Esta forma lexical, no estado do Paraná e de Santa Catarina, manteve-se com percentual próximo, 9,15\% e 8,22\%, respectivamente.

A Figura 9 apresenta a distribuição diatópica das quatro principais variantes documentadas no corpus, excetuando-se a variante "menino", pois, das 42 localidades consultadas, em apenas duas a referida variante não foi registrada: pontos 237 - Vacaria e 247 - Santana do Livramento, no estado do Rio Grande do Sul. $^{19}$

19 Assim como em algumas localidade de Minas Gerais e Rio de Janeiro, na ocasião da elaboração deste trabalho, não estavam disponíveis os dados referentes a duas localidades gaúchas 241 - Santa Cruz do Sul e 244 Osório. 
Figura 9 - Distribuição diatópica das quatro variantes lexicais mais produtivas na rede de pontos da região Sul

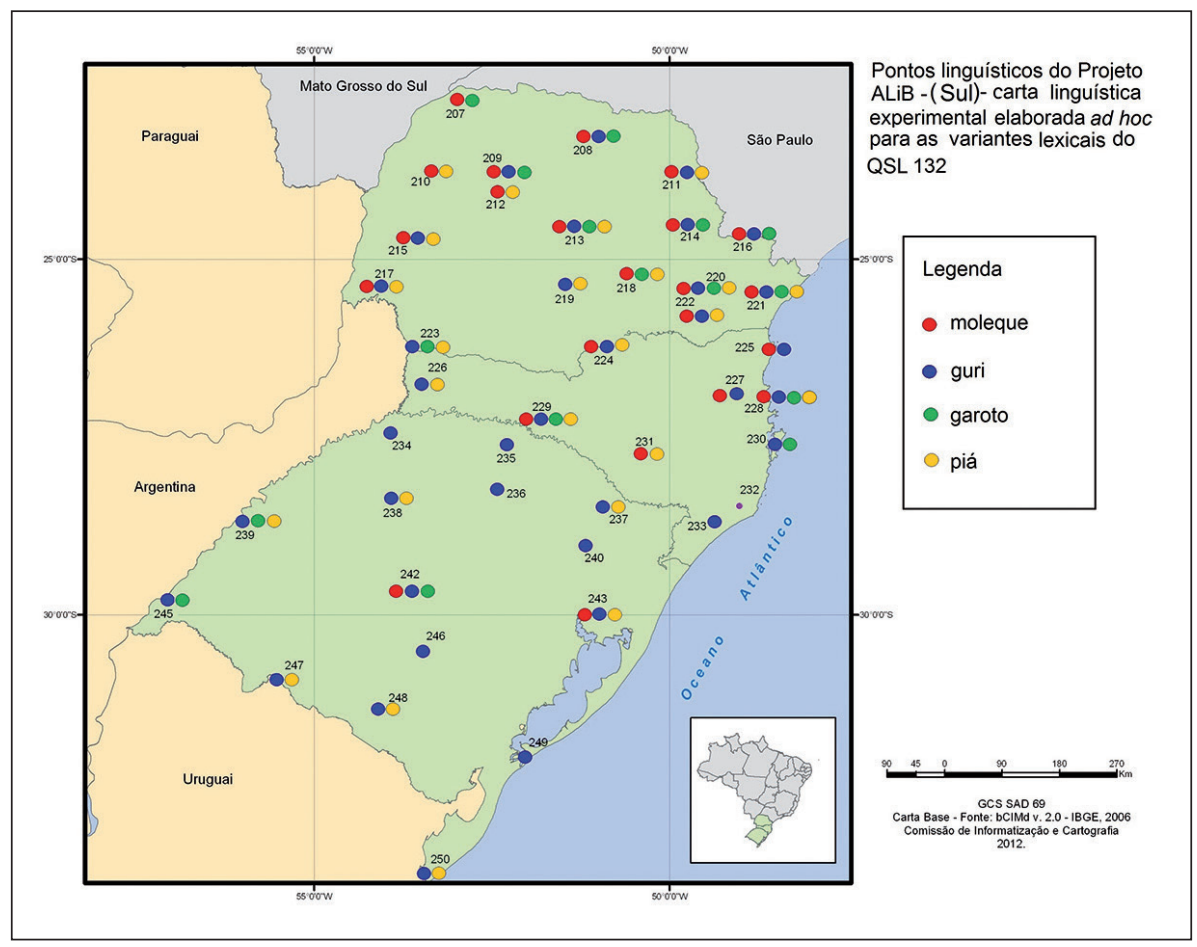

Fonte: Banco de dados do ALiB (2013).

Observa-se que, no ponto 232 - Criciúma/SC, não há registro de nenhuma das quatro variantes elencadas na legenda. Isso se deve ao fato de que nessa localidade houve a ocorrência exclusiva da variante "menino". Assim, a Figura 9 apresenta uma concentração da variante "moleque" no estado do Paraná e em Santa Catarina, pois, dos 17 municípios paranaenses constantes da rede de pontos do estado, esta variante não foi registrada em apenas dois deles, ponto 219 - Guarapuava e 223 - Barracão, localizados no centro e ao sudoeste paranaense. Em Santa Catarina, das dez localidades que contemplam a rede de pontos, esta variante não está presente em cidades próximas ao litoral sul do estado, pontos 230 - Florianópolis, 232 - Tubarão e 233 - Criciúma, e em uma localidade no oeste catarinense, ponto 226 - São Miguel do Oeste. Ao contrário, no Rio Grande do Sul, "moleque" foi registrada apenas em duas localidades, em Porto Alegre - ponto 243 e em Santa Maria - ponto 242; portanto, não se constitui como uma forma típica dos gaúchos para denominar a criança do sexo masculino, haja vista que nas localidades gaúchas a referida variante obteve baixa representatividade. 
Já "guri", assim como a variante "menino", apresentou uma melhor distribuição na região Sul, contemplando o estado do Rio Grande do Sul, adentrando o estado de Santa Catarina, com exceção dos pontos 231 - Lages e 232 - Tubarão. No Paraná, foi documentada em 13 pontos linguísticos, não registrada somente em quatro municípios, dos quais três estão localizados ao noroeste paranaense (ponto 207 - Nova Londrina, 210 - Umuarama e 212 Campo Mourão) e um no centro do estado (ponto 218 - Imbituva), conforme se observa na Figura 10.

Figura 10 - Isoléxica da variante guri nas localidades do estado do Paraná

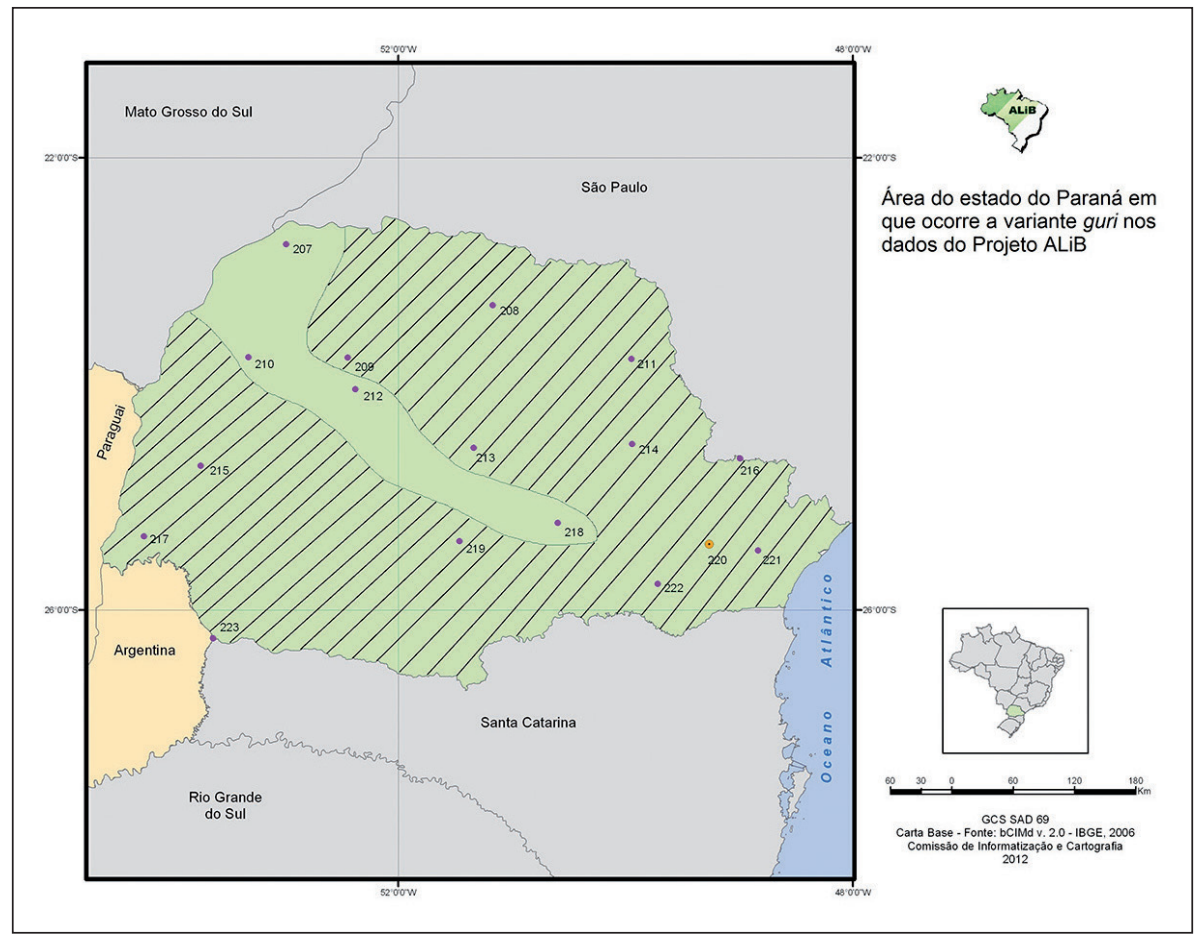

Fonte: Banco de dados do ALiB (2013).

No entanto, em resposta à hipótese nula 7, o teste de Kruskal-Wallis indicou que "guri" não apresentou uma distribuição homogênea na região Sul, apesar de ocorrer na maioria das localidades (Tabela 5). Tal fato pode ser explicado pela grande concentração de ocorrências dessa variante no Rio Grande do Sul (49 registros) se comparada aos estados de Santa Catarina (14 ocorrências) e Paraná (26 ocorrências). Desse modo, a hipótese 7 pode ser rejeitada. 
Tabela $\mathbf{5}$ - Teste de homogeneidade das variantes guri e piá na região Sul

\begin{tabular}{ccccccc}
\hline & Paraná & $\begin{array}{c}\text { Santa } \\
\text { Catarina }\end{array}$ & $\begin{array}{c}\text { Rio Grande } \\
\text { do Sul }\end{array}$ & df & Teste*(p-valor) \\
\cline { 2 - 5 } & $\begin{array}{c}\text { Média do } \\
\text { rank (N) }\end{array}$ & $\begin{array}{c}\text { Média do } \\
\text { rank (N) }\end{array}$ & $\begin{array}{c}\text { Média do } \\
\text { rank (N) }\end{array}$ & & \\
\hline guri & $16,26(17)$ & $15,20(10)$ & $31,63(15)$ & 2 & $16,791(\mathrm{p}<0,001)$ \\
\hline piá & $29,38(17)$ & $15,60(10)$ & $16,50(15)$ & 2 & $12,401(0,002)$ \\
\hline
\end{tabular}

*Teste de Kruskal-Wallis $\quad \mathrm{N}=$ quantidade de localidades

Fonte: Banco de dados do ALiB (2013).

A variante "garoto" apresentou uma maior concentração no Paraná e em Santa Catarina. No território paranaense, foi registrada em nove pontos linguísticos localizados ao norte e a leste do estado, não ocorrendo nos municípios localizados ao sudoeste. Em Santa Catarina, essa variante ateve-se a duas cidades litorâneas, ponto 228 (Itajaí) e ponto 230 (Florianópolis), além de ocorrer em uma localidade a oeste do estado, ponto 229 - Concórdia. No Rio Grande do Sul, "garoto" também foi registrado em três cidades: 239 - São Borja, 245 - Uruguaiana e 242 - Santa Maria.

Observa-se, ainda, na Figura 9, que "piá" se distribui no Paraná principalmente nos pontos linguísticos localizados no centro e no sul do estado, o que permite o traçado de uma linha de isoléxica que não contempla os pontos localizados ao norte e leste paranaense: pontos 207 - Nova Londrina, 208 - Londrina, 209 - Terra Boa, 214 - Piraí do Sul e 216 - Adrianópolis. A ausência dessa variante em cidades próximas à fronteira política com o estado de São Paulo pode ser explicada pelas influências linguísticas oriundas desse estado no norte do Paraná, haja vista que a variante "piá" não é uma forma lexical típica dos paulistas. As influências advindas principalmente de Santa Catarina evidenciam a presença da forma "piá" em municípios do centro e do sul do Paraná, pois, em Santa Catarina, "piá" ocorre em quatro pontos do interior 224 - Porto União, 226 - São Miguel do Oeste, 229 - Concórdia e 231 Lages e na capital, ponto 230 - Florianópolis. Porém, no território "gaúcho", a variante "piá" apresentou uma distribuição esparsa, ou seja, não ocorreu em uma área contínua do estado. Assim, dos 15 pontos a que se teve acesso, a forma lexical "piá" foi registrada em sete municípios, a saber: 237 - Vacaria, 238 - Ijuí, 239 - São Borja, 243 - Porto Alegre, 247 - Santana do Livramento, 248 - Bagé e 250 - Chuí, conforme se observa na Figura 11. 
A hipótese nula 8 consistiu em verificar se "piá" apresenta distribuição homogênea na região Sul. De acordo com os dados das Tabelas 6 e 7, existem evidências estatísticas significantes de uma diferença entre as regiões e a hipótese pode ser rejeitada ( $\mathrm{p}$-valor = 0,002). Assim como ocorreu com a variante "guri", foi verificada uma maior concentração de ocorrências de "piá" no estado do Paraná (45 registros), se comparada aos estados de Santa Catarina (10 registros) e Rio Grande do Sul (16 registros), o que justifica tal resultado.

Figura 11 - Isoléxica da variante piá na região Sul

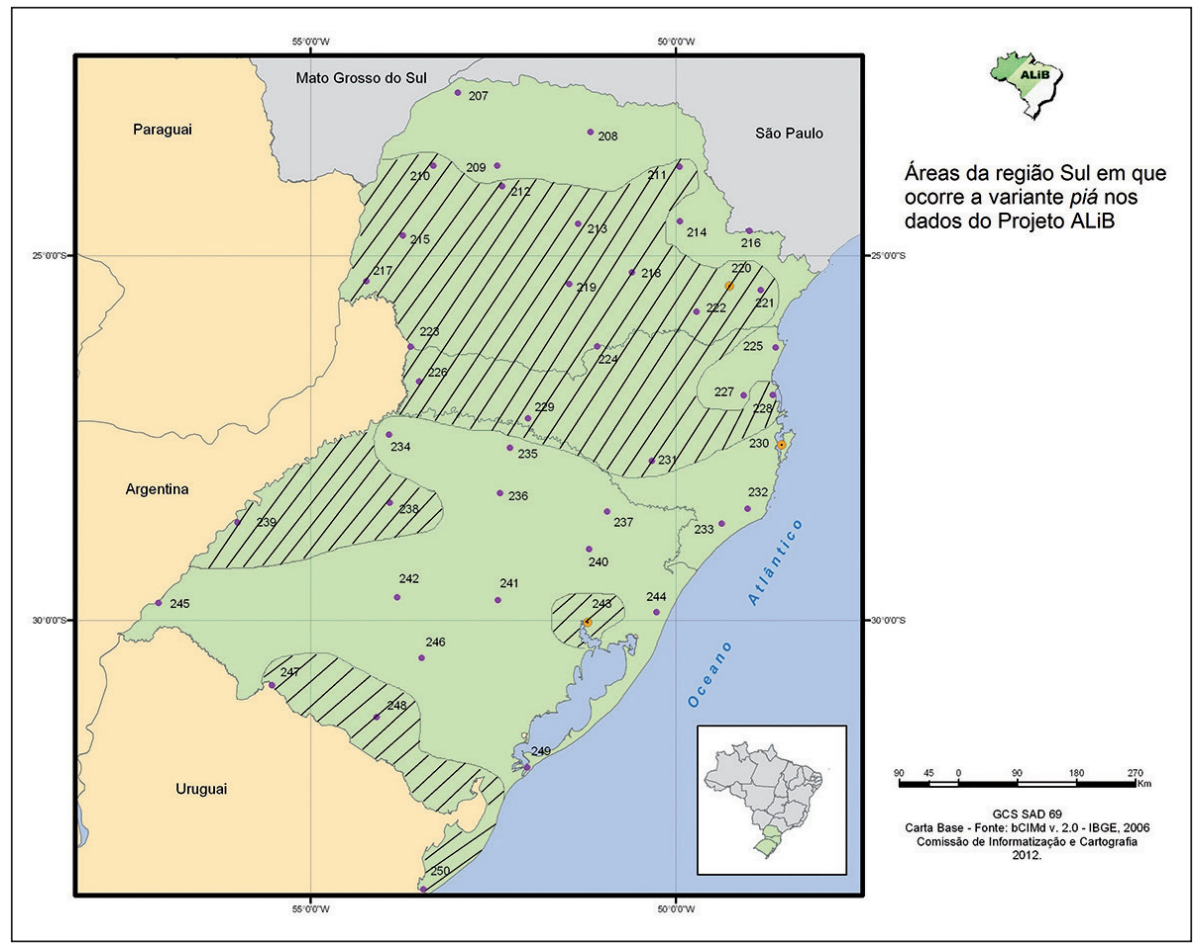

Fonte: Banco de dados do ALiB (2013).

Por fim, na região Sul, houve o registro de quatro variantes menos produtivas. Foram documentadas cinco ocorrências da forma lexical "rapazinho" nos pontos 225 - São Francisco do Sul/SC (três registros), 229 - Concórdia/SC (ocorrência única) e no ponto 248 - Bagé/RS (ocorrência única). A variante "homenzinho" obteve duas ocorrências, uma no ponto 236 - Passo Fundo/RS e outra no ponto 248 - Bagé/RS. A forma "pivete" foi documentada em Guarapuava/PR e em Lages/ SC. Finalmente, como hapax legomena, houve a ocorrência da variante "bambino" em Adrianópolis/PR. 


\section{Considerações finais}

Embora não se utilize o corpus do Projeto ALiB em sua totalidade, este estudo comprova diferenças linguísticas entre os estados e as regiões investigadas. A variante mais difundida na norma lexical do português brasileiro para a questão analisada, considerando o corpus investigado, é "menino", registrada em quase todos os pontos linguísticos.

A pesquisa evidenciou que, no Centro-Oeste, há diferenças linguísticas entre Mato Grosso do Sul e Mato Grosso em relação ao estado de Goiás. Nos dois primeiros, além da predominância da variante "menino", há um índice considerável de registros da variante "guri", típica da região Sul, o que ressalta a semelhança desses estados em alguns aspectos com o Rio Grande do Sul devido a fluxos migratórios. Em Goiás, por sua vez, o índice de ocorrência da variante "guri" é menor, haja vista que esse estado recebeu influências também de outros grupos, além dos bandeirantes paulistas durante o seu processo de ocupação.

A variante "moleque" difunde-se pelas três regiões, constituindo-se como a segunda variante mais produtiva. Essa forma lexical está presente, sobretudo, nos estados em que houve a intensa atuação dos bandeirantes durante o período de escravização do índio e, principalmente, do negro nas áreas mineradoras. Essa variante de etimologia africana não obteve índice de ocorrência considerável no Rio Grande do Sul.

Na região Sul, há três variantes que se destacam: (i) "guri" é a forma mais difundida e mais produtiva no Rio Grande do Sul; (ii) em Santa Catarina, há maior índice de ocorrência da variante "menino"; e (iii) "piá" é a forma lexical mais produtiva no estado do Paraná. Neste estado, a ocorrência dessa variante concentra-se em municípios do centro e sul, não ocorrendo em cidades do norte e leste paranaense. A não ocorrência de "piá" nesta área justifica-se por sua proximidade linguística com o estado de São Paulo.

Por fim, no Sudeste, além de outras formas, há a ocorrência esparsa da variante "guri" em cidades paulistas, mineiras e capixabas, não possibilitando o traçado de isoléxica. "Piá", por sua vez, ocorreu exclusivamente em quatro localidades paulistas localizadas no Vale do Ribeira, o que permite o traçado de uma área de isoléxica. A presença dessa variante nessa região do estado, principalmente em Itapetininga, revela traços da sócio-história, pois sabe-se que o Caminho das Tropas que vinham do Rio Grande do Sul tinha como ponto de passagem algumas cidades paulistas antes de alcançar o destino final, Sorocaba. Portanto, o estudo ratifica a importância de associar aspectos sócio-históricos a dados linguísticos, contribuindo, desse modo, para a melhor compreensão e descrição do português brasileiro. 
ROMANO, V. P.; SEABRA, R. D. Menino, guri or piá? a diatopic study on regions Midwest, Southeast and South from the data of Project Linguistic Atlas of Brazil. Alfa, São Paulo, v.58, n.2, p.463-497, 2014.

- ABSTRACT: This paper uses as corpus of analysis the data collected by the Project Linguistic Atlas of Brazil team in three regions: Midwest, Southeast and South. These data refer to the country cities and to the capitals of each state; they were collected from informants who were selected according to established profiles. On this occasion, the objective was to discuss the diatopical distribution of lexical variants for question number132 - A very young child is called baby. However, when this small kid is 5-10 years old and also is a male person, how is the most commonly used term for calling him? - of Lexical-Semantic Questionnaire (COMITE NACIONAL DO PROJETO ALIB, 2001). The methodology involved descriptive and inferential analysis which were pertinent to the study. Thus, eight hypotheses were tested in order to analyze the behavior and the diatopical distribution of the five most productive variants in the set of answers. The main results indicated that those variants exhibited different behaviors in three different regions: (i) the variant menino showed homogeneous distribution in ten states; (ii) the lexical forms guri and piá had a heterogeneous distribution in the Southern region; (iii) variants of indian etymology (guri and piá) are more representative in the South and Midwest; (iv) there is a greater representation of variant moleque (African etymon) in the Southeast, especially in São Paulo and Minas Gerais.

- KEYWORDS: ALiB Project. Dialectology. Lexical variants.

\section{REFERÊNCIAS}

AGUILERA, V. A. De onde vieram e por onde andam as nossas libélulas e jacintas? um estudo da etimologia popular com base em dados do Atlas Linguístico do Brasil (ALiB). Estudos Linguísticos e Literários, Salvador, n.41, p.291-309, 2010.

BLUTEAU, R. Vocabulario Portuguez \& latino: aulico, anatomico, architectonico. Coimbra: Collegio das Artes da Companhia de Jesus, 1712 - 1728. 8v. Disponível em: <http://www.brasiliana.usp.br/pt-br/dicionario/edicao/1> Acesso em: 17 dez. 2012.

COMITÊ NACIONAL DO PROJETO ALIB. Atlas Linguístico do Brasil:questionários 2001. Londrina: EDUEL, 2001.

CUNHA, A. G. Dicionário histórico das palavras portuguesas de origem tupi. 5.ed. São Paullo: Melhoramentos; Brasília: Ed. da UnB, 1999.

Dicionário etimológico Nova Fronteira da língua portuguesa. 2.ed. Rio de Janeiro: Nova Fronteira, 1986.

DIÉGUES JÚNIOR, M. Regiões culturais do Brasil. Rio de Janeiro: INEP/MEC, 1960. (Série VI, Sociedade e Educação, v.2).

DUARTE, A. C. O Centro-Oeste na organização regional do Brasil. In: IBGE. Geografia do Brasil: região Centro-Oeste. Rio de Janeiro: IBGE, 1989. v.1, p.15-20. 
DUBOIS, J. et al. Dicionário de linguística. Tradução de Frederico Pessoa Barros et al. São Paulo: Cultrix, 1991.

FERREIRA, A. B. de H. Novo dicionário da língua portuguesa. Versão eletrônica 5.0. 3.ed. Curitiba: Positivo, 2004.

GALVEZ, J. A. (Ed.). Dicionário Larousse Francês/Português, Português/Francês. São Paulo: Larousse do Brasil, 2005.

HOUAISS, A.; VILLAR, M. de S. Dicionário eletrônico Houaiss da língua portuguesa. Versão 1.0. Rio de Janeiro: Objetiva, 2001.

ISQUERDO,A. N. O caminho do rio, o caminho do homem, o caminho das palavras. In: RIBEIRO, S. S. C.; COSTA, S. B. B.; CARDOSO, S. A. M. (Org.). Dos sons às palavras: nas trilhas da língua portuguesa. Salvador: EDUFBA, 2009. p.41-59.

. Designações para estilingue em atlas lingüísticos brasileiros: perspectivas diatópica e sócio-histórica. In: CONGRESS INTERNATIONAL DE LINGUISTIQUE ET DE PHILOLOGIE ROMANES. 24., 2007, Tübingen. Actes.... Tübingen: Max Niemeyer Verlag, 2007. t.1, p.533-546.

MACHADO, J. P. Dicionário etimológico da língua portuguesa. Lisboa: Editorial Confluência, 1952. 2 t.

MAGALHÃES, M. N.; LIMA, A. C. P. Noções de probabilidade e estatística. 3.ed. São Paulo: IME-USP, 2001.

MANDEL, E. O significado da segunda guerra mundial. São Paulo: Ática, 1989.

MARINS, L. G. F. O rural e o urbano: novos e velhos falares na região CentroOeste do Brasil. 2012. 310f. Dissertação (Mestrado em Estudos de Linguagem) Universidade Federal do Mato Grosso do Sul, Campo Grande, 2012.

NASCENTES, A. Dicionário etimológico resumido. Rio de Janeiro: Instituto Nacional do Livro, 1966.

O linguajar carioca. 2.ed. Rio de Janeiro: Organizações Simões, 1953.

PAIM, M. M. T. A variação lexical nos campos semânticos corpo humano e ciclos da vida: o que revelam os dados do Projeto ALiB. Diadorim: Revista de Estudos Linguísticos e Literários, Rio de Janeiro, n.8, p.143-159, 2011.

RIBEIRO, D. O povo brasileiro: a formação e o sentido do Brasil. 2.ed. São Paulo: Schwarcz: Companhia das Letras, 1995.

ROMANO, V. P.; AGUILERA, V. de A. Distribuição diatópica para as variantes para tangerina: um estudo geo-sociolinguístico. In: ISQUERDO, A. N.; ALTINO, F. C.; AGUILERA, V. de A. (Org.). Atlas Linguístico do Brasil: descrevendo a língua, formando jovens pesquisadores. Londrina: UEL, 2009. p.148-157. CD-ROM 1. 
SILVA, A. M. Dicionário da língua portugueza. 2.ed. Lisboa:Typographia Lacerdina, 1813.

SILVA, L. M. da; AGUILERA, V. de A. Variantes lexicais para o gambá: um estudo geolinguístico nas capitais brasileiras. In: CIELLI - COLÓOUIO INTERNACIONAL DE ESTUDOS LINGUÍSTICOS E LITERÁRIOS, 1., 2010, Maringá. Anais... Maringá: Universidade Estadual de Maringá, 2010. p.1-13.

SILVA-COSTA, D. de S.; ISQUERDO, A. N. Um estudo etnolinguístico de designativos para 'gambá' no Brasil Central: contribuições do Projeto ALiB. Estudos Linguísticos, São Paulo, v.41, n.2, p.779-792, 2012.

SPSS for Windows. Version 17.0. [S.1]: IBM, 2008. 1 CD-ROM.

STECA, L. C.; FLORES, M. D. História do Paraná: do século XVI à década de 1950. Londrina: Ed. da UEL, 2002.

VIEIRA, S. Análise de variância: Anova. São Paulo: Atlas, 2006.

YIDA, V. O campo semântico da alimentação e cozinha no Atlas Linguístico do Brasil: um estudo lexical nas capitais. 2011. 191f. Dissertação (Mestrado em Estudos da Linguagem) - Universidade Estadual de Londrina, Londrina, 2011.

Recebido em janeiro de 2013.

Aprovado em maio de 2013. 
